\title{
Documentos sobre el papel de los árabes hilālíes en el al-Andalus almohade: traducción y análisis
}

\author{
Documents Related to the Role of the Hilāli Arabs in \\ al-Andalus During the Almohad Period: Translation \\ and Analysis
}

\author{
José Ramírez del Río \\ Universidad de Córdoba, España
}

La llegada de los árabes hilālíes al territorio del actual Marruecos, llamados por los califas almohades, ha generado una gran polémica entre historiadores; su aportación al ejército almohade también es conocida desde hace décadas. Sin embargo, la actuación de estas poblaciones en al-Andalus y su difícil coexistencia con la población local no ha sido objeto de trabajo alguno hasta la fecha. Las noticias aparecidas en una serie de cartas de cancillería nos permiten ofrecer un acercamiento a la presencia de estas poblaciones en el sur de al-Andalus, que resultó de gran importancia en el declive de los almohades y en el desmoronamiento de su poder en la península Ibérica.

Palabras clave: Almohades; Hilālíes; al-Andalus; Cancillería.
The arrival of the Hilāli Arabs in the territory of today's Morocco, called by the Almohad Caliphs, has raised a great controversy among the historians of the Maghreb; their contribution to the army of this empire is also well known since several decades. However, the activities carried out by the Hilāli Arabs in alAndalus and the uneasy relationships with the local population have not been dealt with to date. The information provided by a collection of chancellery letters will hopefully allow us to study the effects of their presence in southern al-Andalus, which was of paramount importance for the decline and the eventual loss of the Almohads' control over the Iberian Peninsula.

Key words: Almohads; Hilāli Arabs; al-Andalus; Chancellery.

\section{Introducción}

La intervención almohade en la península Ibérica ha dado lugar en los últimos años a una gran cantidad de bibliografía ${ }^{1}$ que ha cambiado

${ }^{1}$ Cfr. Cressier, Fierro y Molina (eds.), Los Almohades: problemas y perspectivas; Fierro, "The Almohads (524-668/1130-1269) and the Hafșids (627-932/1229-1526)" y Fierro, The Almohad Revolution. Politics and Religion in the Islamic West During the TwelfthThirteenth Centuries. 
en buena medida la evaluación de este período histórico; diferentes aspectos han recibido una atención cuidadosa por parte tanto de medievalistas como de arabistas y de especialistas de otras ramas de los estudios históricos. El ejército almohade ya había sido estudiado de forma profunda por Ambrosio Huici Miranda, cuyas obras siguen siendo imprescindibles al abordar esta época ${ }^{2}$, y la presencia de los árabes denominados hilālíes en las unidades militares almohades también ha sido tratada en trabajos recientes ${ }^{3}$. Curiosamente el expediente usado por los almohades de dirigir sus fuerzas contra los cristianos cumpliendo el precepto del $\hat{y} i h \bar{a} d$, ya había sido utilizado en épocas anteriores por dirigentes árabes locales para combatir a genoveses y normandos en las costas de Túnez ${ }^{4}$, por lo que suponía una mera incorporación de una de las líneas políticas más importantes del territorio tunecino en la dinámica del imperio almohade 5 .

Sin embargo, si bien el impacto social de su actuación en el Magreb ha sido tan atacado en el pasado como polémico en las últimas décadas ${ }^{6}$, apenas encontramos referencias a su implantación en al-Andalus y al impacto que tuvo sobre las poblaciones andalusíes.

2 Así, dos de sus obras fundamentales han sido reeditadas recientemente por la Universidad de Granada: Las grandes batallas de la Reconquista durante las invasiones africanas e Historia política del imperio almohade.

3 Aguilar, "Aportación de los árabes nómadas a la organización militar del ejército almohade"; Aguilar, "Instituciones militares: el ejército"; García Fitz, Las Navas de Tolosa; Burési, "D'une péninsule à l'autre: Cordoue, 'Utmān (644-656) et les arabes à l'époque almohade (XIIe-XIIIe siècle), esp. pp. 17-23.

${ }^{4}$ Tawfìq al-Ṭayibī, "Banū Hilāl wa-dawru-hum fị l-ŷihād fì Ifrīqiyya wa-l-Andalus ilà nihāyat al-qarn al-sādis/al-țānī 'ašar al-mîlādī'.

${ }^{5}$ La entrada de las tribus árabes en el juego político local, incluso como mercenarios del imperio almohade, alteró profundamente las formas de vida en adelante; cfr. Rodríguez Mediano, "The Post-Almohad Dynasties in al-Andalus and the Maghrib (seventh-ninth /thirteen-fifteenth centuries)".

${ }^{6}$ Cfr. Julien, Histoire de l'Afrique du Nord, p. 374 ss; Idris, La Berbérie orientale sous les Zirides: Xème-XIIème siècles y Marçais, La Berbérie musulmane et l'Orient au Moyen Âge, por un lado, frente a Poncet, Paysages et problèmes ruraux en Tunisie, o Lacoste, El nacimiento del Tercer Mundo: Ibn Jaldún, pp. 95-115. El primer grupo señala el carácter catastrófico de la llegada de los árabes hilālíes a Túnez, mientras que el segundo intenta relativizar la importancia de dicho acontecimiento. Recientemente Michael Brett ha relacionado las formas narrativas de este episodio en las crónicas árabes con la identidad tribal yemení que los zīríes habían falseado; cfr. Brett, Ibn Khaldun and the Medieval Maghrib, cap. VIII a X. y Brett, "The Central Lands of North Africa and Sicily, until the Beginning of the Almohad Period". 
Posiblemente una de las razones fuera apuntada ya por V. Aguilar? señalar los daños de unas tropas pertenecientes al estado almohade sobre los andalusíes sería acusar, en las crónicas cortesanas de la época, al propio califa. Así, Ibn Șāhịib al-Ṣalā nos informa acerca de la participación de los árabes en diferentes campañas ${ }^{8}$ pero no de su asentamiento y menos aún de sus saqueos contra los andalusíes.

Sin embargo, en los últimos años, hemos asistido a la aparición de múltiples documentos de una naturaleza diferente: las cartas de cancillería, también emanadas del poder político pero, necesariamente, pegadas a la realidad. E. Lévi-Provençal ${ }^{9}$ ya había hecho uso de este tipo de fuente y publicó una recopilación de las mismas; las obras de M. Bencherifa ${ }^{10}$ también ofrecieron un buen número de ejemplos, al estudiar las vidas de algunos de los funcionarios almohades ( $k u t t a \bar{b}$ alinša') y la publicación de las colecciones de cartas llevadas a cabo por Ahmad 'Azzāwi $\overline{1}^{11}$ han aumentado en gran medida la documentación disponible; en estas líneas intentaremos mostrar su importancia. Tenemos que destacar por último los trabajos de P. Burési, que aprovecha este material de cancillería para avanzar en algunas cuestiones poco conocidas de la historia de los almohades ${ }^{12}$.

El traslado de combatientes árabes desde la zona de Túnez hasta alAndalus tenía dos objetivos fundamentales: dividir a una población muy levantisca, alejándolos en lo posible de su tierra natal para facilitar su control y usar su capacidad militar, en especial para la guerra irre-

7 Aguilar, “Aportación de los árabes nómadas”, p. 393.

8 Ibn Sāhib al-Salā, al-Mann bi-l-imāma, pp. 251, 441-442.

${ }^{9}$ Lévi-Provençal, Documents inédits d'histoire almohade: fragments manuscrits $d u$ "Legajo » 1919 du fonds arabe de l'Escurial; Lévi-Provençal, "Trente-sept lettres officielles almohades".

${ }_{10}$ Bencherifa, Ibn al-Mugāwir al-Šātibī; Bencherifa, Ibn Lubbāl al-Šarīšì.

11 'Azzāwī, Rasā'il muwahhidiyya; 'Azzāwī, Rasā'il dīwāniyya muwahhidiyya; 'Azzāwī, Qadàyā tā'rijiyya jilāl al- 'așrayn al-muwahhidì wa-l-marīnī. También resulta interesante para un período histórico posterior al-Magrib wa-l-Andalus fi l-qarn al-sābi'. Como señalan Burési y El Aallaoui (Governing the Empire, Provincial Administration in the Almohad Caliphate (1224-1269), p. 91), 'Azzāwī no incluyó en la colección de cartas que editó en 1995 ninguna de las presentadas por Lévi-Provençal, aunque en la compilación de 2006 cambió de criterio.

12 Burési y El Aallaoui, "La chancellerie almohade”, pp. 477-503; Burési, "Les plaintes de l'archevêque: chronique des premiers échanges épistolaires entre Pise et le gouverneur almohade de Tunis (1182)"; Burési, "Traduttore traditore: à propos d'une correspondance entre l'Empire almohade et la cité de Pise (début XIII siècle)". 
gular, contra los cristianos en al-Andalus, antes de que la volvieran contra el propio poder almohade ${ }^{13}$.

La mala reputación de los árabes hilālíes se encuentra en el centro de las disputas mencionadas anteriormente acerca de la historia del Magreb. La rapiña ejercida sobre la población sedentaria de las regiones por las que pasaban era tan violenta que dos fragmentos de Ibn Jaldūn se repiten con insistencia en la bibliografía consultada ${ }^{14}$. Es evidente que a pesar de los profundos cambios que supuso la llegada de los hilālíes al territorio actual de Túnez, no se les puede achacar una decadencia de siete siglos; tal idea resulta absurda. Sin embargo los daños causados a la población de la zona sí fueron reales, y como puede observarse en el caso andalusí pudo tener efectos definitivos sobre la relación entre almohades y andalusíes.

\section{Fuentes}

Los elementos con los que contamos para la elaboración del presente trabajo son las fuentes escritas árabes, tanto andalusíes como magrebíes, contemporáneas de los hechos y algunos informes arqueológicos que nos aportan fundamentalmente información acerca del contexto en que se desarrollaron las acciones narradas en las fuentes árabes. Los informes arqueológicos pertenecen en su casi totalidad a excavaciones de urgencia llevadas a cabo en la región de Sevilla y publicadas en el Anuario Arqueológico de Andaluciá15, y que por su

${ }^{13}$ Lo expresa de manera meridiana el califa Yūsuf al-Manșūr: «A estos árabes, atendedlos y halagadlos y tratadlos con la mayor bondad; empleadlos en las expediciones y no los dejéis en el ocio y el descanso»; cfr. Ibn 'Idārī, al-Bayān al-Mugrib. Qism al-muwahhidìn, al-Kattānī et al. (eds.), p. 232.

${ }^{14}$ Ibn Jaldūn, al-Muqaddima, p. 149 ed. Beirut, p. 311 trad. México: «La índole montaraz de los árabes [bi-tabíat al-tawahhuš́] ha hecho de ellos un pueblo de pilladores y bandoleros. Saquean cuanto pueden sin exponerse a los peligros ni sostener una lucha; no vacilan en apoderarse de cuanto alcanza su mano huyendo luego al fondo del desierto, donde pastorean sus ganados»; y pp. 270-271 ed. Beirut, p. 493 trad. México: « [...] han hecho de

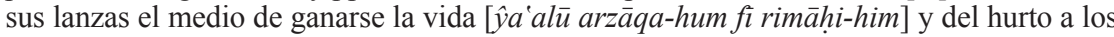
demás el modo de subsistir. Por ello declaran la guerra a quien quiera defender sus pertenencias. Su objeto no va más allá del botín; no pretenden hacerse con un rango ni fundar un imperio: su única preocupación, su máxima meta, es saquear a las demás gentes».

15 Publicados por la Consejería de Cultura de la Junta de Andalucía con un retraso que va de los tres a los cinco años desde la realización de la actividad arqueológica. Vid notas n. ${ }^{\circ}$ 58-60. 
misma naturaleza suponen un gran mérito de las personas que los llevan a cabo en condiciones de trabajo muy difíciles y en un tiempo muy reducido. Gracias a ellas podemos constatar una actividad constructiva muy intensa por parte del imperio almohade para fortificar las regiones en las que habitaron los árabes hilālíes; no tenemos noticia de ningún trabajo en que se haya localizado a través de la actividad arqueológica la presencia de esta población de origen norteafricano. El análisis de este tipo de trabajos se encuentra, por tanto, relativamente alejado de los objetivos de esta investigación.

Las fuentes escritas son de dos tipos: fuentes cronísticas orientales y andalusíes y las cartas de cancillería almohades, redactadas por secretarios o escribas de las cortes almohades de los gobernadores de Sevilla y de funcionarios de menor rango de la misma administración.

\subsection{Fuentes cronisticas orientales y andalusies}

Encontramos en Oriente fuentes cronísticas que enfatizan el papel de combatientes por la fe de los árabes de Ifrìqiyya ${ }^{16}$, aunque las menciones resultan muy sucintas. Las fuentes andalusíes principales para el período almohade no suelen incidir en el asunto abordado en estas páginas, ni en el caso de los diccionarios bio-bibliográficos ni en crónicas como al-Mann bi-l-imāma o al-Bayān al-Mugrib, aunque la crónica al-Mu'ŷib fi taljịs ajbār al-Magrib ${ }^{17}$ [Lo admirable en el resumen de las noticias del Magreb] de 'Abd al-Wāḥid al-Marrākušī nos resarce en buena medida de esa ausencia de noticias en otras crónicas.

Tenemos relativamente pocos datos del autor del $M u \cdot \hat{y} i b$ : nacido en Marruecos hacia 1185, realizó estudios en el Magreb y en al-Andalus, hasta que en 1217 decidió emigrar a Oriente, donde vivió y trabajó hasta su muerte. Su obra al-Mu ŷib fi taljịs ajbār al-Magrib ${ }^{18}$ la compuso para un personaje poderoso de Bagdad, interesado por la historia de al-Andalus y abarca desde la conquista hasta 1224, basando sus

${ }^{16}$ Ibn al-Atīir, al-Kāmil fì l-ta'rīj, IX, pp. 41, 245-246; Fagnan, Ibn El-Athir. Annales du Maghreb et de l'Espagne, p. 590; Burési, “D’une péninsule à l'autre”, pp. 20-21.

17 Ed. Dozy, The History of the Almohades; trad. al francés de Fagnan, Histoire des almohades y trad. al español de Huici Miranda, Lo admirable en el resumen de la Historia del Magreb.

18 Lévi-Provençal, “"Abd al-Wāḥid al-Marrākušì”, en $E I^{2}$; Viguera Molins, "Historiografía”, p. 10; Maíllo, De Historiografía árabe, pp. 143-144. 
datos de los últimos años en noticias recibidas a través de cartas y viajeros llegados desde al-Andalus.

Las críticas a este autor y a su fiabilidad han sido muy acerbas, en especial Mállo no le atribuye apenas valor alguno, tanto por escribir de memoria algunas partes como por usar fuentes con numerosos elementos literarios, como la partida de ajedrez entre Alfonso VI e Ibn 'Ammār ${ }^{19}$ y otras narraciones de marcado carácter literario. Sin negar que su información para las épocas previas resulta difícilmente fiable, no podemos afirmar lo mismo para los sucesos de los que ${ }^{\circ} \mathrm{Abd}$ alWāhiid al-Marrākušì fue testigo, en los que nos transmite acontecimientos que podemos contrastar, en algunas ocasiones, por otros medios y que han resultado ciertas hasta el momento ${ }^{20}$. Consideramos por tanto fiables las noticias que transmite acerca de los árabes en al-Andalus, que pertenecen al período inmediatamente anterior a su marcha hacia Oriente y a un emplazamiento geográfico y a unas poblaciones que el autor conocía sobradamente.

\subsection{Cartas de cancillería almohades}

En los últimos años tanto P. Burési como Hicham El Aallaoui han explotado las cartas de cancillería en unos trabajos que hemos ido citando en estas páginas y que han dado lugar recientemente a un estudio sobre la administración provincial almohade ${ }^{21}$. Aunque los documentos incorporados se refieren a una época más tardía, nos ofrecen información contextual relevante.

La primera carta de cancillería acerca del traslado de los árabes de Ifrīiyya a al-Andalus es conocida desde hace décadas, concretamente la de Abū l-Faḍl b. Țāhir b. Mahšara dirigida a los almohades de Cór-

19 Al-Marrākušī, al-Mu'ŷ̀ib fì taljīs ajbār al-Magrib, pp. 83-84.

${ }^{20}$ En este sentido resulta llamativo que, como señala Muhammad al-Manūnī, un crítico tan severo como Dozy concediera una importancia inestimable a las noticias de alMarrākušì para la época almohade, que lo condujo a titular The History of the Almohades una historia general del Occidente islámico; cfr. al-Manūn̄i, al-Mașādir al-'arabiyya lita'rīj al-Magrib, p. 50; Dozy tenía una opinión muy similar a la de Maíllo para la información de al-Marrākušī sobre el período de taifas; cfr. Dozy, The History of the Almohades, pp. 10-11.

${ }^{21}$ Cfr. Governing the Empire: Provincial Administration in the Almohad Caliphate (1224-1269).

Al-Qantara XXXV 2, 2014, pp. 359-396 ISSN 0211-3589 doi: 10.3989/alqantara.2014.014 
doba $^{22}$. Sin embargo las cartas de cancillería almohades, que ofrecen la parte más relevante de la información de este trabajo fueron editadas por Aḥmad 'Azzāwīi ${ }^{23}$ y por Muḥammad Bencherifa ${ }^{24}$.

\subsubsection{Aḥmad 'Azzāwī}

Editó textos procedentes de dos manuscritos diferentes: el manuscrito J.M. 6148 de la biblioteca Hassāniyya de Rabat, que contenía los seis últimos capítulos de al- 'Ață' al-yazìl fì kašf gață' al-tarsī ${ }^{25}$ [El regalo generoso, obra sobre la redacción epistolar], del secretario de cancillería sevillano Aḥmad al-Balawī (Sevilla 1179-Marrakech 1260) ${ }^{26}$. Este tipo de obras fueron muy comunes en el Magreb en este período, como atestigua la obra de Bruna Soravia ${ }^{27}$ y la publicación de otros libros de este género ${ }^{28}$, como Kanz al-kuttāa wa-muntajab al-ādāb [Tesoro de los escribas y selección literaria], de Abū Isḥāq Ibrāhīm b. al-Hasan al-Būnsi ${ }^{29}$. Con ellos se buscaba formar a los secretarios que habían de trabajar en las administraciones de los estados magrebíes, tanto en los aspectos formales de las cartas, con sus encabezamientos y sus fórmulas de presentación, como en las nociones de historia lite-

${ }^{22}$ Maŷmū' rasā'il muwahhidiyya min inšă' kuttāb al-dawla l-mu'miniyya, ed. LéviProvençal, p. 152.

23 'Azzāwī, Rasā'il muwahhidiyya, I, pp. 315-327.

${ }^{24}$ Bencherifa, Ibn al-Mugä̀ir al-Šătibì.

${ }^{25}$ Esta obra fue objeto de la tesis doctoral inédita de Muḥammad Miftāḥ, defendida en la Universidad Complutense de Madrid en 1990. La directora de la misma, la Dra. Viguera Molins, señala la importancia de esta obra en "Historiografía", pp. 3-37, especialmente 28 y nota 182. Al-Manūnī precisa que se trataba de los capítulos quince a veinte de la obra, sin que pudiera encontrar la parte que falta en otros manuscritos; cfr. al-Mașādir al-'arabiyya li-ta'ríj al-Magrib, pp. 62-63. Recientemente Pascal Burési y Hicham El Aallaoui han tratado este manuscrito como complemento del 6148; cfr. Governing the Empire, pp. 91-92.

${ }^{26}$ Vid supra.

27 Soravia, "Un traité andalou d'adab al-kātib d'époque almoravide: l'Ihkām Șanāat al-Kalām d'Ibn 'Abd al-Gafür de Séville"; Soravia, "Les manuels arabes à l'usage des fonctionnaires de l'administration (adab al-kātib) à l'âge classique de l'Islam"; Soravia, "Ibn Qutayba en al-Andalus. La préface à l'Adab al-Kätib dans le commentaire d'Ibn alSīd al-Bațalyawsī”.

${ }_{28}$ Acerca del arte y la técnica de los secretarios esperamos la publicación de la tesis doctoral de Hicham El Aallaoui, L'art du secrétaire entre littérature et politique: les actes des chancelleries almoravide et almohade, dirigida por P. Guichard en la Universidad de Lyon-Lumière II y leída el 28 de junio de 2007.

29 Editada por Hayat Qāra. 
raria necesarias para llevar a cabo su oficio. Por ello, las cartas en ocasiones no aparecen completas, dado que la función didáctica asignada a dichas obras hacía innecesario que así fuera; como no se buscaba conservar el valor documental de las cartas, en ocasiones se omiten los topónimos o los nombres de los grupos tribales concernidos por dichos textos; aunque el editor de las mismas, Aḥmad 'Azzāwī, atribuye dicha carencia a la negligencia de los copistas, esta explicación no está reñida con la anterior.

A este manuscrito corresponden las cartas 1, 2, 3, 4 y 7 y según señala al- 'Azzāwī, la letra del mismo es andalusí y bastante antigua, aunque no llevó a cabo un análisis paleográfico que pudiera indicarnos la fecha exacta de su copia.

El segundo manuscrito sobre el que llevó a cabo su edición era propiedad del famoso bibliófilo y erudito marroquí Muhammad al-Manūnī, cuya biblioteca se dispersó tras su muerte el 28 de agosto de 1999, sin que tengamos referencia de la ubicación en estos momentos del manuscrito indicado ${ }^{30}$. Dado que no incluyó noticias del mismo en su obra ya citada, al-Mașādir al-'arabiyya li-ta'rīj al-Magrib, tenemos que suponer que llegó a su poder con posterioridad a 1983. A este manuscrito pertenecen las cartas número 5 y 6 .

Sin embargo, podemos saber algunas características de estos manuscritos gracias a las indicaciones de ${ }^{~} A z z a ̄ w i{ }^{31}$. El compilador de las cartas del primer manuscrito fue el andalusí Ahmad b. Muhammad b. 'Abd al-Raḥmān Abū 1-Qāsim; al-Quḍāè y luego al-Balawīin': Sevillano, cordobés de ascendencia; su grupo tribal, los al-baluliyūn son de Qaḥ̣̂ān, de los que vivían en el Hiŷāaz antes del Islam. Y los antepasados de este Abū 1-Qāsim eran conocidos en Córdoba como los Banū 'Alī. Nació faltando catorce noches del mes de ŷumàdà II del

${ }^{30}$ Afortunadamente este conjunto documental había sido ya copiado y el Dr. Bencherifa contaba con una copia del mismo; cfr. Ibn Lubbāl al-Šarī̌šì p. 14, nota 26.

${ }^{31}$ Rasā'il muwahhidiyya, I, pp. 15-16. Años después de la edición de 1995, en un homenaje a la memoria de al-Manūnī, 'Azzāwī declaró que este manuscrito, aun tratándose de una copia relativamente reciente y con una serie de páginas perdidas, se trataba de una recopilación de cartas del propio al-Balawī, posiblemente de alguno de los capítulos perdidos de al-'Atā al-ŷazìl; cfr. 'Azzāwī, "Min nawādir al-maktaba al-manūniyya", pp. 37-63.

${ }^{32}$ Ibn 'Abd al-Malik al-Marrākušì, al-Dayl wa-l-takmila, p. 674; Ibn Sa'īd al-Magribī, Ijtișār al-qidh, pp. 120-122; al-Maqqarī, Nafh al-țìb, IV, p. 300; VI, pp. 155, 206-207, 358359, VIII, p. 252; Ibn al-Jațīb, al-Iḥạta fi ajbār Garnāța, II, p. 483; 'Azzāwī, Rasā'il muwahhidiyya, p. 32. 
año $575^{33}$, y trabajó como juez. En las fuentes se menciona que fue juez de Marbella y Estepona el año $606^{34}$; en su juventud trabajó como escriba de varios gobernadores de Sevilla y de otras ciudades, como Abū Zayd y Abū Mūsà 'Isà, hijos del califa 'Abd al-Mu'min, de 'Umrān b. Abī Mūsà, Abū Isḥāq, el hijo del califa Yūsuf y con otro Abū Ishạā, hijo del califa al-Manșūr, y con Abū l-Rabīe b. Abī Hafṣ b. 'Abd al-Mu'min; después pasó al campo de la judicatura. Vivió un tiempo en Marrakech posteriormente y volvió a esta ciudad con una delegación sevillana ante el califa al-Sa ${ }^{1} i d$ al-Mu'tadid en el año $640^{35}$. Murió en ramadân del año $657^{36}$ cuando contaba con ochenta y dos años lunares.

El visir al que iban dirigidas varias de las cartas de al-Balawī era Ibn Ŷāmie, una de las figuras más destacadas de la administración almohade de su tiempo. De hecho Bencherifa atribuye a su padre, 'Abd Allāh b. Ibrāhīm Ibn Ŷàmie una gran relevancia en la decisión de instalar a los árabes en las zonas cercanas a Jerez en dirección a Sevilla ${ }^{37}$. El citado personaje tenía sus orígenes familiares en la costa de Jerez, en la alquería de Rota, por lo que mostró un particular interés por la protección de la región, aparentemente asegurada por la instalación de los árabes hilālíes; el Ibn Ŷàmie al que se dirigen las cartas era su hijo, Abū Sa īd, visir de al-Mustanșir y su interés por refrenar los abusos contra la población local, unido a su posición en la corte, justifican también que las cartas sobre este asunto le fueran dirigidas a él.

\subsubsection{Muhammad Bencherifa}

La tarea de Bencherifa en la recuperación del legado de los secretarios de cancillería almohades ha sido de gran importancia. En el caso que nos ocupa, consiguió editar tanto los fragmentos poéticos como los de prosa contenidos en el principal título de Ibn al-Mugāwiri ${ }^{38}, N \bar{u} r$

33 Correspondiente a mediados de diciembre de 1179.

34 Mediados de 1209 a junio de 1210.

${ }^{35}$ De julio de 1242 a junio de 1243.

${ }^{36}$ Agosto-septiembre de 1259.

37 Esta relación fue puesta de manifiesto por Bencherifa, Ibn Lubbāl al-Šarī̌š , p. 14. Acerca de la carrera de este personaje, vid. al-Marrākušì, al-Mu'ŷib, pp. 228 y 238.

${ }^{38}$ Cfr. Gallego Ortega, "Ibn al-Mugāwir", en ECA, I, 4, pp. 219-224. 
al-kamā'im wa-šây' al-hamà 'im [Las flores de los cálices y el zureo de las palomas], a los que añadió las cartas de cancillería escritas por este personaje y conservadas en la misma obra de al-Balawī, al-'Ața 'al$\hat{y} a z \bar{l} l$, y en el mismo manuscrito, el J.M. 6148 de la biblioteca Hassaniyya de Rabat. La carta de Ibn al-Mugāwir en la que se apoya este trabajo procede de la obra Nür al-kama'’im wa-ša $\hat{y}^{\prime}$ al-ham $\bar{a}^{\prime} i m$, inserta en un manuscrito encontrado por Bencherifa en Tamgrout, en la zāwiya al-Nāșiriyya, n. $^{\circ}$ de registro 1580 y hoy día inaccesible. Este manuscrito, una copia de la obra original con numerosos errores de copia y con alteraciones pero con una letra clara, no ha sido objeto de un estudio codicológico completo y no podemos avanzar más detalles sobre el mismo.

Abū Bakr b. 'Abd al-Raḥmān b. Muḥammad b. Mugāwir b. Hakam b. Mugāwir al-Sulāmī, conocido por Ibn al-Mugāwir (Játiva, 1108/1109-Játiva, marzo de 1191) ${ }^{39}$, era de familia árabe asentada en Córdoba, que emigró a Levante durante la guerra civil de comienzos del siglo XI y que desempeñó diferentes cargos relacionados con la judicatura y el gobierno de Játiva. Ibn al-Mugāwir comenzó su carrera como secretario en la administración almorávide, pasando a servir a Ibn Mardanī̌s y posteriormente a los almohades tras la rendición de la familia de éste. Tras servir al gobernador Abū Hafṣ 'Umar b. 'T̄sà, a la muerte de éste en 1174 pasó al servicio de Abū 1-Rabī b. 'Abd Allāh b. 'Abd al-Mu'min, al que acompañó en sus desplazamientos a Sevilla que dieron origen a la carta que insertamos en el presente trabajo. Durante el gobierno de Abū l-Rabī en Valencia y Murcia, Ibn al-Mugāwir acompañó a Abū l-Rabīe en su paso por Marrakech, donde algunas cartas del 'Ațâ' al-ŷyzil lo sitúan, y posteriormente se retiró a su Játiva natal cuando su señor fue destinado al Magreb Central. Prestó servicios ocasionales a los gobernadores locales hasta su muerte, acaecida entre el 9 y el 19 de marzo de 1191.

La carta que nos interesa para este estudio fue redactada, por tanto, por un funcionario de alto rango del imperio almohade que tenía la in-

39 Al-Dahabī, Siyār a lām al-nubalā', XXI, pp. 150-151; Ibn al-Abbār, al-Mu'ŷam fi aṣhāb al-qā dì al-imām Abì 'Alì al-Șadafi, pp. 243-245; Ibn al-Abbār, al-Takmila li-Kitāb al-Șila, pp. 571-572 (n. ${ }^{\circ}$ 1622); Ibn al-Abbār, Tuhfat al-qadìm, pp. 25, 28-29; Ibn Idrīs, Zād al-musāfir, pp. 37-40; Ibn al-Jațīb, al-Ihạtta, IV, p. 303; Ibn Sa īd, al-Mugrib fi hulà l-Magrib, pp. 385-386; Ibn Zubayr, Șilat al-șila, III, n. ${ }^{\circ} 341$; al-Maqqarī, Nafh al-țìb, II, p. 73; III, p. 331; IV, p. 342; V, p. 62 . 
tención de detallar las diferentes etapas de su viaje a su señor, Abū 1$\mathrm{Rabi}^{\mathrm{i}}$, y consideramos que su información resulta digna de confianza.

Tenemos que señalar que 'Azzāwī, el editor de buena parte de las cartas, indica en sus escritos que los bereberes Kūmíes también participaban, de manera notable, en los ataques contra la población. La indisciplina de estas tropas ni era nueva ni había cesado desde la llegada de los almohades a Sevilla, como podemos comprobar en diferentes ocasiones; sin embargo, los lazos tribales que unían a los dirigentes de estas tropas con los gobernantes almohades siempre permitieron encauzar de manera diferente los conflictos. Así, la construcción de una zona amurallada en la alcazaba de Sevilla permitió limitar el daño que causaba esta tropa en la ciudad ${ }^{40}$. Sin embargo varios de los ataques más graves no son atribuibles a ellos, como el asesinato del hargí, que en puridad pertenecía al mismo grupo bereber del que procedían los Banū 'Abd al$\mathrm{Mu}^{\prime} \min ^{41}$, y las menciones a los árabes en las cartas son más numerosas.

\section{La llegada de los hilālíes a al-Andalus}

Los árabes a los que se refiere la fuente son conocidos de forma genérica como los hilālíes ${ }^{42}$, aunque como señalan las fuentes hubo grupos tribales diferentes. Se trataba de una confederación de tribus árabes (Banū Sulaym, Banū Riyāḥ, Banū Hilāl...) que tras ser dirigidas por los gobernantes fătimíes de Egipto hacia Túnez en el siglo X, según algunas fuentes para vengarse de la defección de los gobernadores de este territorio, destrozaron este país hasta el punto de ser considerados la causa de su larga decadencia. Brett ha mostrado de forma convincente que el movimiento de estos grupos hacia Túnez había comenzado antes de los conflictos entre fătimíes y zìríes ${ }^{43}$.

Tras la conquista de la actual Túnez por los almohades en el siglo XII, fueron trasladados en masa ${ }^{44}$ hacia el Magrib al-Aqșà (actual te-

40 Viguera Molins, "La ciudad almohade de Sevilla", pp. 15-30.

${ }^{41}$ Acerca de la genealogía de 'Abd al-Mu’min, vid. Fierro, "Las genealogías de ‘Abd al-Mu'min, primer califa almohade".

${ }_{42}$ Brunschvig, La Berbérie orientale sous les Hafșides des origines à la fin du XVème siècle; Abu-Nasr, A History of the Maghrib, pp. 96-99; Shatzmiller, The Berbers and the Islamic State: the Marinid Experience in Pre-Protectorate Morocco.

${ }^{43}$ Brett, "The Central Lands of North Africa", pp. 48-65, esp. pp. 54-55.

${ }^{44}$ Tras la derrota, siguieron siendo el factor político decisivo en Túnez y en Tremecén, durante al menos siglo y medio más. Sólo la llegada de los otomanos eliminó su dominio 
rritorio marroquí) y al-Andalus, con consecuencias desastrosas para las poblaciones bereberes ${ }^{45}$, que sufrieron sus depredaciones durante los siguientes dos siglos, perjudicando tanto a los almohades como a los Banū Marīn. De hecho se convirtieron en un factor de inestabilidad tal que sólo cuando el poder central era capaz de garantizar por la fuerza la defensa de las regiones agrícolas del centro de Marruecos frente a sus asaltos, se conseguía un cierto grado de prosperidad económica y de estabilidad política. Por estas razones expuestas anteriormente parece poco probable que estas poblaciones, muy problemáticas en el Magreb, contribuyeran a la estabilidad de una región de al-Andalus como Bādiyat Istiŷŷa ${ }^{46}$ donde, como podremos ver más adelante, llevaron una vida errante alejada del poder almohade, causando cambios en las formas de vida de los habitantes. Las descripciones acerca de las diferentes poblaciones de Bādiyat Istiŷya en los siglos IX y X nos muestran una clara preponderancia de las actividades agrícolas y de la silvicultura, mientras las cifras del botín alcanzado por las incursiones castellanas en el siglo XIII parecen mostrar un cambio hacia unas actividades ganaderas. Este cambio pudo iniciarse en el siglo XI, aunque los análisis de pólenes de las excavaciones arqueológicas citadas anteriormente no parecen apuntar en esta dirección; posiblemente fue la inmigración de los elementos árabes lo que motivó esta alteración ${ }^{47}$.

La llegada de los almohades a Sevilla supuso un cambio demográfico en Bādiyat Istiŷŷa debido a un factor al que no se ha prestado la atención necesaria hasta el momento: la llegada de los árabes hilālíes, procedentes de Túnez, que fue registrada por al-Marrākušši ${ }^{48}$ :

[...] después de esto volvió 'Abd al-Mu'min a Marrākuš, tras enviar a las distintas regiones de al-Andalus unidades de caballería y de infantería de los mașmūda y de los árabes, y de otros tipos de tropas (min așnāf al-ŷund), pues cuando había querido pasar a la península reclutó muchas entre los habitantes del Magreb, y entre los re-

en esta parte del Magreb, aunque siguieron ejerciendo un poder importante en Qayrawān hasta la época colonial.

${ }^{45}$ Rodríguez Mediano, “The Post-Almohad Dynasties”, pp. 106-107 y pp. 120-121.

${ }^{46}$ La Estepa de Écija, territorio que venía a ocupar las actuales comarcas de la Campiña de Sevilla y la Sierra Sur. Acerca de este territorio cfr. Ramírez del Río, Entre ulemas y bandidos: la Estepa de Écija en al-Andalus, (en prensa).

${ }^{47}$ Ramírez del Río, Entre ulemas y bandidos.

48 Al-Marrākušì, al-Mu'ŷib, pp. 159-161. Todas las traducciones de textos árabes que se presentan en este artículo son responsabilidad del que subscribe, salvo indicación expresa en sentido contrario. 
clutados se encontraban los árabes del país de Yahyà b. 'Abd al-'Azīz, que son de las tribus de Hilāl b. 'Āmir. Éstas salieron hacia ese territorio cuando los Banū ${ }^{~} U_{b a y d}{ }^{49}$ dejaron libre el camino hacia el Magreb; causaron en Qayrawān graves daños que llevaron a su decadencia hasta el día de hoy y destrozaron el reino de los Banū Zīrì b. Manād. [...] Se mantuvieron así con él y con su hijo, el denominado al-'Azìz, y en tiempos de Yahyà hasta que se apoderó del país Abū Muhammad 'Abd al-Mu'min -Dios lo tenga en Su gloria- que les arrebató el poder, los convirtió en un ejército suyo y apartó a algunos de sus dirigentes de aquel país. Les escribió una carta y los reclutó para la incursión en la península de al-Andalus [...].

Le respondió una gran multitud, y aunque quisieron alejarse de la península, les asignó puestos en ella; puso a algunos en los alrededores de Córdoba (nawāhì Qurtuba) y a otros en los de Sevilla, colindando con Jerez y sus distritos (nawāhì IĹsbìliyya mimmā yalì madīnat Šarī̌s wa-a'māli-hā). Ellos permanecieron allí hasta el momento presente, que es el año 621 [1224 A.D]. Se propagaron muchos de sus descendientes en estos lugares; Abū Ya qūb y Abū Yūsuf trajeron más hasta el punto de que son muy numerosos en esas regiones hoy en día los árabes de Zigba, Riyāh, Ŷušam b. Bakr y otros. Hay cerca de cinco mil caballeros, además de infantería. El paso de 'Abd al-Mu'min -Dios lo tenga en Su gloria- y su estancia en Ŷabal al-Fath [Gibraltar] fue en el año 548 [1153 A.D].

La presencia de los árabes en algunas regiones de al-Andalus adoptó un carácter permanente y cambió de forma importante algunas regiones del país. Las comarcas de Sevilla que lindaban con Jerez se refieren, evidentemente, a Bādiyat Istiŷŷa, donde confluían los caminos que unían Sevilla y Córdoba con el Estrecho. Como podremos comprobar en el apartado cuarto, en ocasiones esos árabes se veían reforzados por otros de su mismo origen que residían de forma habitual en el Magreb, dando lugar a graves problemas algo que, en al-Andalus, se producía de manera permanente.

\section{Permanencia del contingente árabe hilālí en al-Andalus}

Las dudas acerca de la permanencia de estos elementos han estado presentes en diferentes obras, pues las referencias de al-Marrākuš̄i inseguras por la forma en que redactó su obra y las numerosas licencias con la realidad histórica que podemos encontrar en el $M u$ y $y i b$, forzaban a la cautela. Sin embargo las cartas que veremos más adelante nos llevan a descartar estas dudas. Contamos con un testimonio veinte años posterior

${ }^{49}$ Los Banū 'Ubayd eran los fățimíes; cfr. Nicol, A Corpus of Fātimid Coins. 
a la llegada de los hilālíes a al-Andalus y su mera exposición arroja luz sobre el grado de desvertebración del territorio, de desobediencia al poder político almohade y de alteración de las formas de vida de los andalusíes, que tuvieron que cambiar su forma de ganarse la vida para adaptarse a la llegada de estos elementos. Las referencias tanto por parte de los secretarios de cancillería como por parte de los cronistas nos fuerzan a ser muy cuidadosos en el análisis de estos documentos, pero la reiteración de la información por diferentes vías facilita su toma en consideración.

La descripción del territorio controlado por los árabes hilālíes corre a cargo de un alto funcionario almohade, que se dirige a Játiva desde Sevilla donde estaba sirviendo al sayyid almohade Abū l-Rabï'. Las condiciones de vida en la zona, muy cercana a Sevilla, resultan muy llamativas:

\section{Viaje de Ibn al-Mugāwir por Bādiyat Istîŷy $a^{50}$}

Dijo Ibn al-Mugāwir-Dios le haya perdonado-: Estaba en Sevilla-Dios la protejacon el gran señor [al-sayyid al-aŷal] Abū l-Rabî -Dios le ayude- y añoré mi región y mi patria chica, mi morada de Játiva -Dios la proteja- por lo que pedí permiso a Abū l-Rabīe para volver a ella, para que me enviara en misión allí. Él aceptó, no me lo negó y me colmó, con su extrema generosidad, de regalos y dones, y me permitió montar su hermosa yegua, el mejor de sus caballos. Desde Játiva escribí a Abū 1-Rabīe -Dios le ayude- describiéndole mi viaje jornada tras jornada, día tras día.

$[\ldots]$

A su excelencia el señor excelso, único, grande y virtuoso Abū l-Rabīe, único en su especie por sus virtudes y gracias cuantiosas, hombre de mirada clara y de firmes propósitos. La generosidad de su nobleza se refleja en las flores de sus virtudes ¡que Dios le haga llegar Su favor, alargue su vida y la colme de favores y de grandeza! De su siervo Ibn al-Mugāwir, un noble saludo, siempre atento a su servicio ¡Que Dios el Excelso tenga misericordia de él y le otorgue Su bendición! [...].

Cuando vuestro siervo tomó vuestra mano bendita el lunes doce de rabī II del año 571 [29 de octubre de 1175], al prepararme para alejarme de la sede del imāmato, que no de vuestro buen natural ni de mi inclinación por serviros, sino para reforzar los lazos con los críos, que como aves de pluma se golpean los unos a los otros «pues nuestros hijos están entre nosotros y nuestros enemigos marchan sobre la tierra». Me acerqué al establo ${ }^{51}$ de vuestros caballos para montar, los más dignos y rápidos en ir y en volver, [hermosos como] rosa que adorna la chilaba [al-ŷallāba]

${ }^{50}$ Bencherifa, Ibn al-Mugāwir al-Šătibī, pp. 167-169.

${ }^{51}$ Estos establos, situados cerca de la Puerta de Carmona, posiblemente daban nombre a una zona de la ciudad de Sevilla, Kudyat al-Jayl (la roca de los caballos), de la que las 
al atardecer, y resplandece su lucero en su faz como una estrella, que casi se inflama. Me enderecé en su lomo y casi en seguida subí a una colina hasta su lejana cima, hasta que plegó su garganta hacia mí a derecha y a izquierda: avanzó por las cuestas gimiendo y lamentándose, jadeando y divulgándolo [...].

La montura se apaciguó y llegó a su zancada normal, y me llevó al paso. Se calmaron los corceles y emprendieron una marcha fuerte en un terreno dificultoso. La yegua miraba unas veces a sus cascos de color terroso y otras veces dirigía la mirada hacia al-Jadrā ${ }^{52}[\ldots]$.

Salió el siervo de mi señor por la Puerta de Carmona, y ya le alegraban sus esperanzas, y veía la bendición en su movimiento seguro. Lo bueno en él va parejo pues yo estaba, mi señor, en su lomo como en un lecho mullido y en un lugar de gran poderío, hasta que llegamos a un collado al final de las cisternas [bahâa'ir] de nuestro señor el amìr al-mu'minìn, al que Dios ayude con Su previsión, y quizá pretendían [los caballos] despedirse entonces allí; dobló las riendas quien se despidió y se olvidó de ello quien se olvidó, pero a todos nos entristeció la nostalgia de la separación [...]. Nos llegó la paz del saludo en este camino y llenamos la copa de lágrimas con pétalos y con las galas del camino. Recorrimos el tapiz de aquella campiña [fahs] extensa y su campo hasta que nos detuvimos al anochecer de aquel día en Mayrāna ${ }^{53}$. Jornada [II]: Pasamos la noche en las ruinas [talal] despobladas, en los patios, y no nos recostamos sino a la sombra de sus muros inclinados. El vigía acechaba el destino desde las esquinas, y avisaba de que se venía abajo por la destrucción de su estructura [bi-tahaddum bunyāni-him], como si hablara al que pasaba junto a él el del abandono de los pobladores. [Estuvimos allí] hasta que la claridad de la serena mañana hizo desaparecer la oscuridad, el céfiro del alba apareció entre la tiniebla y la noche se dobló entre los vientos. Cabalgamos los corceles con brío al amanecer, mirando los desfiladeros y los collados, mientras pendía sobre nosotros el ataque de los ladrones y de las fieras salvajes en estas comarcas [al-așq $\left.\bar{a}^{\prime}\right]$ y en estos abismos en los que vagaba 'Adī b. al-Riqā ${ }^{-54}$, hasta que llegamos a Osuna [Ušuña] la noche del miércoles, deseando dar gracias a Dios.

fuentes nos han transmitido sobre todo la presencia de un cementerio. Acerca del cementerio, vid. Valencia, Sevilla musulmana hasta la caída del califato: contribución a su estudio, p. 582. El texto que estamos tratando confirma la hipótesis apuntada por Torres Balbás en el sentido de que Kudyat designa un barrio situado en un cerro o en un otero; cfr. Ciudades hispanomusulmanas, I, p. 173.

${ }_{52}$ Se refiere a que dirigía la vista al frente, pues salían por el camino hacia Algeciras (al-Jaḍrā'). Esta ciudad cobró una gran importancia durante el dominio de los imperios norteafricanos, como han puesto de manifiesto los estudios de Antonio Torremocha; $\mathrm{cfr}$. Torremocha, Algeciras entre la Cristiandad y el Islam; Pérez-Blanco y Pérez-Blanco, "Protección y tratamiento urbanístico de las murallas medievales de Algeciras", pp. 111-127.

${ }^{53}$ Este topónimo ha sido identificado como Mairena del Alcor por el propio Bencherifa, editor del texto en árabe.

${ }^{54}$ Poeta de la corte omeya de Damasco que alcanzó renombre por sus panegíricos a varios califas y por sus descripciones de gacelas y de la vida del desierto. Se trata de un poeta secundario y poco conocido, con lo que el autor busca mostrar su erudición; cfr. Tahsīn Muḥammad Șalāḥ, 'Adī b. al-Riqa' al-'Amilì: hayātu-hu wa-ši'ru-hu; Hasan Muham-

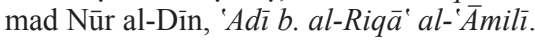


Jornada [III]: Dos potros, a pesar de la mucha prudencia y de la seguridad [con que avanzábamos] fueron alcanzados por unos juncos [al-sāma $]$ e hicimos aquella mañana una distancia más corta, por lo que decidimos que el recorrido aquel día fuera más corto, y llegamos a Wādī al-tịn [El río Guadalete $]^{55}$. En Wādī al-tịn había una gente vestida como si fueran demonios [zayy al-šayātīn] y con el orgullo de sultanes, beduinos como los cuervos ${ }^{56}$ y eran apóstoles del mal y «iSálvate fulano, pues allí crucificaron a mengano!». Pasamos junto a ellos y la veneración por vuestros sultanes velaba sus miradas, y nos dejaron sus seguidores y sus ayudantes, hasta que llegamos a Faŷŷ al-mașālib ${ }^{57}$ la noche del jueves, a un puesto militar nuestro, cuyos [integrantes] se unieron a nosotros ese día.

Como podemos observar el territorio se encontraba tan desarticulado que ni tan siquiera pudo utilizar un funcionario almohade de alto rango las vías descritas por al-Idrīsī en el siglo XII; la fortaleza de Osuna había sustituido a Écija como cabecera del territorio y sólo cambiaría esa situación tras la reconstrucción por parte de los almohades de la muralla de la ciudad; los habitantes no cuidaban de mantener las pistas de caballería, no ya las vías, en buen estado e incluso un grupo con una fuerte escolta como la de Ibn al-Mugāwir temía encontrarse con una partida de árabes beduinos. Solo la acción continuada del califato almohade, que invirtió en reconstruir las ciudades de este territorio una gran cantidad de medios, permitió recuperar el control de la región. En efecto, la investigación arqueológica, cuya ampliación sería muy necesaria, ya ha documentado la realización de obras muy importantes en las décadas finales del siglo XIII en Écija ${ }^{58}$, Osuna $^{59}$, Marchena ${ }^{60}$ y otras localidades de Bādiyat Istiŷŷa.

${ }^{55}$ Cfr. Terés, Materiales para el estudio de la toponimia hispano-árabe. Nómina fluvial, pp. 226-227.

${ }_{56}$ Estos beduinos eran sin duda una partida de árabes pertenecientes a los contingentes desplazados por 'Abd al-Mu'min a la región situada entre Sevilla y Jerez, suceso referido anteriormente y que conocemos gracias a al-Marrākušì.

57 Seguramente se trata de Puerto Serrano, cerca de Coripe.

${ }^{58}$ Hay partes de la muralla almohade en que la construcción no puede más que calificarse de apresurada y poco sólida; cfr. Martín Muñoz, "Intervención arqueológica de urgencia en c/ Mendoza n. ${ }^{\circ} 3$ a c/ Bermuda de Écija (Sevilla)", p. 1015. El establecimiento de estas dos fases pudo constatarse en excavaciones anteriores en otras partes de la ciudad; cfr. Collado Ruiz, Romero Paredes y Carrasco Gómez, "Intervención arqueológica de urgencia en un solar sito en calle Merinos n. ${ }^{\circ} 38$ de Écija (Sevilla)", pp. 657-663; Carrasco Gómez y Vera Cruz, "Intervención arqueológica de urgencia en c/ Bodegas 5 esquina a c/ Merinos. Écija (Sevilla)", pp. 1288-1297. El tercer momento pertenece ya a la época cristiana, en que el espigón fue perforado para construir un pasadizo que hiciera más fácil el tránsito. Sáez, Ordóñez y García-Dills, "La cerca islámica de Écija”, p. 256; Carrasco 


\section{El contingente árabe tras la batalla de las Navas de Tolosa}

La actuación de los árabes hilālíes en la batalla de las Navas de Tolosa no resultó en absoluto brillante, aunque tal cosa resultaba previsible. Sin apenas espacio para maniobrar, el enfrentamiento de una caballería ligera como era el caso con una pesada como la feudal de los reinos cristianos, no podía tener otro resultado ${ }^{61}$. Sin embargo vamos a tratar en las próximas páginas de la actuación de los árabes con la propia población andalusí durante los tiempos que siguieron a las Navas, cuando la fuerza militar de los hilālíes fue dirigida en buena medida contra la propia población andalusí.

Contamos con una colección de cartas en que funcionarios de diferentes niveles del imperio, desde el gobernador de Sevilla hasta algún gobernador militar de los alrededores de Sevilla se coordinan para intentar frenar la actuación rapaz de árabes hilālíes ${ }^{62}$.

Gómez y Romero Paredes, "Intervención arqueológica de urgencia en plaza de Giles y Rubio n. ${ }^{\circ}$ 9, esquina a c/ Bodegas, a c/ Berberisa y a plaza de Giles y Rubio n. ${ }^{\circ} 19$ de Écija (Sevilla)", pp. 576-579. En este lugar, que limitaba con la muralla almohade y con el río, había una zona de uso doméstico en época romana que fue reaprovechada en época almohade como cementerio.

59 Ruiz Cecilia, "Control arqueológico en la plataforma exterior de la Universidad de Osuna (Sevilla), 2002”, pp. 551-552; Sánchez Gil de Montes y Salas Álvarez, "Intervención arqueológica de urgencia en el solar c/ Asistente Arjona 6-8, Osuna (Sevilla). El arrabal oeste de la ciudad almohade de Uxuna", p. 677. De hecho aunque los autores sostienen la pertenencia de esta zona a la superficie urbana de Osuna, tampoco descartan en absoluto la posibilidad de que se trate de un asentamiento rural periurbano; el hecho de que se encuentre cerca de la Torre del Agua puede abonar la hipótesis de la pertenencia de esta zona al interior de la ciudad. Florindo Sánchez, "Intervención arqueológica de urgencia en plaza de Santa Rita n. ${ }^{\circ} 6$ y 7, Osuna (Sevilla)”, pp. 937-943.

${ }^{60}$ Ferrer (coord.), Arqueología en Marchena. El poblamiento antiguo y medieval en el valle medio del rio Corbo; García Vargas y Díaz Martín, "Excavación arqueológica de urgencia en la calle Zurbarán n. ${ }^{\circ} 2$ (Marchena, Sevilla)", pp. 610-612 y García Vargas y Díaz Martín, "Excavación arqueológica de urgencia en la calle Carrera 35 (Marchena, Sevilla)", pp. 613-619. Los autores sostienen la realización de las obras de la muralla de Marchena en un solo momento constructivo, en la primera mitad del s. XIII, y consideraron que las intervenciones en la muralla de Pedro Ponce de León en 1430 y las de Rodrigo Ponce de León no tuvieron en modo alguno la importancia de las construcciones almohades.

${ }^{61}$ García Fitz, Las Navas de Tolosa, pp. 320-332.

62 'Azzāwī, Rasā’il muwaḥhidiyya, cartas 90-96, pp. 315-327. 


\title{
Carta número $1^{63}$
}

\begin{abstract}
$\mathrm{Al}$ jeque excelente, poderoso y generoso, gobernador destacado, el virtuoso Abū $\mathrm{Sa}^{e} \overline{1}{ }^{64}$, hijo del jeque excelso Abū Muhammad, hijo del difunto jeque excelente Abū Isḥāq-que Dios prolongue sus fuerzas y aumente su honor, que él vea incrementado el favor, el amor y la cercanía de Dios el Altísimo sobre él.

En nombre de Ibrāhīm, hijo de nuestro señor el califa, que era también hijo de nuestro señor el califa ${ }^{65}$.

El saludo humilde a vuestra excelencia y la bendición y el perdón de Dios estén con vos. Además de recordar la bendición de Dios en su justa medida $[\ldots]^{66}$ desde Sevilla, que Dios la preserve, [...] Además de todo ello, que Dios aumente vuestro poder, hay un asunto de importancia sobre el que quiero llamar vuestra atención y que estoy seguro de que requiere consejo y resolución por vuestra parte, acerca de la situación de unos sujetos de Fulāna ${ }^{67}$, que Dios los enderece, pues ellos han devastado aquellas comarcas, se han excedido dañando a sus gentes, destrozándoles con sus imposiciones, atacándolos y asaltándolos. Sus ataques ya han alcanzado un grado de salvajismo preocupante, siendo muy injustos y opresivos con los súbditos, de lo que éstos esperan salvarse gracias a la bondad de la Alta Autoridad ${ }^{68}$ -que Dios la haga perdurar-. Y hago llegar a Su Excelencia la justeza del temor de los súbditos por sus sembrados, que son el sostén de sus vidas y lo que les da sustento y comida. Ha alcanzado a los súbditos lo terrible por sus muchos daños, temen la prolongación de esta situación y de sus perjuicios. Y desesperan de sus sembrados, preparados para lo peor pues no les queda sino ser presa de las garras del león. Ya han rogado y multiplicado sus peticiones, a veces por la muerte de
\end{abstract}

63 'Azzāwī, Rasā'il muwahhidiyya, carta n. ${ }^{\circ}$ 90, pp. 316-318.

${ }^{64}$ Se trata del célebre secretario de cancillería Ibn Ŷāmi', según señaló el propio editor de las cartas. Vid. infra.

${ }^{65}$ Ibrāhīm b. Yūsuf b. 'Abd al-Mu'min.

${ }^{66}$ Bendiciones y saludos comunes a todas las cartas de cancillería almohades y que no añado por no fatigar al lector de forma inútil. Hay ejemplos sobrados en las mencionadas obras de E. Lévi-Provençal y más recientemente en la de Burési y El Aallaoui, Governing the Empire, esp. pp. 255-497. Si bien en esta obra se abordan documentos un poco posteriores a los que atañen a este trabajo, algunos de ellos permiten contextualizar ciertas situaciones que se produjeron en este asunto. Así, el nombramiento n. ${ }^{\circ} 41, \mathrm{pp}$. 385-386 de un jeque árabe para la región de Casablanca y el n. ${ }^{\circ} 32$, pp. 365-366 de un gobernador para apaciguar una rebelión, muestra la panoplia de actuaciones de la administración almohade para lidiar con situaciones como las descritas en las cartas de nuestro estudio.

${ }^{67}$ En las recopilaciones documentales, que tenían en muchos casos intención didáctica, se eliden en muchas ocasiones los nombres propios concretos y se sustituye por el genérico Fulāna, en femenino o Fulān, de donde viene la palabra española, y se usa ya sea para los topónimos, como veremos a continuación, grupos tribales o personas concretas; en este caso se refiere a los combatientes árabes del ejército almohade.

${ }^{6}$ Acerca de la expresión al-amr al-'alī ver el libro de Peña et al., El mensaje de las monedas almohades. 
uno al que aquellos han querido asesinar y otras por unos daños que les ocasionan, cuya carga los debilita y les trae todo tipo de males.

Se apoderan de los frutos, de la mayor parte y no dejan sino lo menos. E hicieron en Fulāna ${ }^{69}$ lo que ya llegó a vuestro conocimiento; sus gentes pretenden vaciarla, huir de ellos y dejarles las propiedades que tienen allí, huyendo de las crueldades contra ellos y del terror. ¡Y cuánto zumo ${ }^{70}$ hubo allí el año pasado! [, pero en este,] no se recogió para sus dueños sino lo menos. Y sobre el del futuro, no tienen esperanza alguna los dueños, según mencionaron. Y una de estas noches un grupo de ellos se ha lanzado contra una de las partes de Fulāna; sus habitantes han pedido ayuda y se han defendido.

Entonces los fulaníes alegaron que uno de ellos había sido muerto en la región mencionada habiendo sido encontrado [su cadáver] cerca de la aceña de un hombre de [la tribu] de Hargà que vivía allí desde hacía mucho tiempo. Atribuyeron su muerte a éste, cerca de la aceña del cual, afirmaban, el muerto había sido encontrado.

El gobernador del lugar cumplió con su deber y aprisionó al hombre para calmar los ánimos. Entre los de Fulāna, la efervescencia creció a tal punto que entraron por la fuerza en la prisión del lugar en pleno día y degollaron al hargí mencionado con sus propias manos. Luego volvieron sus manos contra los súbditos y se propasaron con ellos. Les impusieron pesados tributos y les amenazaron con quemar los cultivos, extender los asesinatos y hacerles perecer a todos. Y de esta misma forma se comportaron en las localidades cercanas, como Zutana, Mengana y Zu$\operatorname{tana}^{71}$. Y en todo el tiempo no dejaron de persistir en sus agresiones. La gente se quejó ante él, [viz. el gobernador] pero no respondió ni hizo movimiento alguno para detenerlos, ni se hizo nada por atajar la situación.

Surgió de aquel grupo alguien que dijo y anunció que se estaban excediendo en causar daños para que así se atendiera su asunto y se les permitiera cruzar el Estrecho y dejar el ejército, y que, de lo contrario iban a seguir en sus agresiones tanto como pudieran y estuviera a su alcance ${ }^{72}$. Habiendo alborotado ya a los súbditos, éstos estaban protestando a gritos, atrayendo la atención del gobierno y elevando las voces con peticiones de ayuda y socorro. Y llamaron a la sede de la justicia [hadarat al-'adl], que es ayuda para el oprimido y refugio del ofendido y del apesadumbrado quejándose por los acerbos males que les habían alcanzado, fuera de toda medida y explicación, por el daño ya recibido hasta ese momento y por el perjuicio que esperaban se iba a producir al impedirles que recogieran lo sembrado. Y la gente de Fulāna jura que si no se sostienen con el grano que tienen allí y no se sustentan con lo que consigan, no permanecerán en ella más y saldrán

${ }^{69}$ Nombre indeterminado de una población en las cercanías de Sevilla. Del conjunto de cartas podemos determinar su identificación con Santiponce.

${ }^{70}$ El término 'așir se emplea para el resultado de exprimir uvas, higos y otros frutos del verano y del otoño, por lo que en ocasiones puede tratarse de mosto, zumo de frutas... o vino; cfr. Bencherifa, Ibn Lubbāl al-Šarīšì, p. 20, nota 46.

${ }^{71}$ Nombres genéricos que sustituyen a los reales de la misma forma que Fulān o Fulāna.

${ }^{72}$ Ya al-Marrākuš̄i señaló esa petición por parte de los árabes hilālíes, que no fue atendida por 'Abd al-Mu'min, que los asentó entre Sevilla y Jerez; cfr. al-Mu’ŷib, pp. 159-161. 
de allí con sus gentes, con sus hijos, huyendo de los daños que han recibido ya, que no pueden soportar y que no padecerán más allí, pues les asaltan las casas, se apoderan con violencia de sus hijas menores, de sus bienes, sea de día o de noche y los matan, tanto en público como en secreto. En sus aldeas se tiene un miedo que los forzará a huir de ellas. No hay nadie que tenga fuerza para detener a los fulāna. Los fulāna se han apoderado de la cosecha por la fuerza en todas las comarcas en que se encuentran y han extendido la devastación en todas partes; es un espanto para los hombres, las mujeres y los niños y las gentes están, en todas partes, muy afectadas. Esperan la mirada del gobierno, anhelan la atención del lugar sagrado [al-maqām al-qudsì]. Temen que perderán los bienes y la esperanza en caso de que se retrase la asistencia generosa y la piedad del centro del imāmato [al-maqām al-imāmī] -Dios el Altísimo favorezca-y atienden el apremio -si Dios quiere- del socorro. Se aprestan con el arma del tiempo y esperan que se aleje de ellos la agresión, esperando la vuelta de la seguridad y la salvación.

Ya os hemos dado a entender todo aquello que era necesario de esta cuestión, y no queda aspecto alguno por conocer y por informar. Vos, si Dios quiere, alcanzaréis la generosa recompensa que os corresponde y el renombre al que vuestros buenos oficios e influencia benéfica os hacen acreedor y que alegran con su brillo a la capital del imāmato [al-hadra al-imāmiyya] -Dios la apoye-, pues Él observa a los siervos de aquella, todo lo ve con agrado y lo envuelve con Su misericordia.

Según el editor, esta carta puede fecharse por comparación con la noventa y dos, que es de muharram de 612, en el año 611, a finales ${ }^{73}$.

La tribu de Hargà era muy destacada en el movimiento almohade por ser la de origen del Mahdī Ibn Tūmart, y recibieron señalados favores del califa 'Abd al-Mu'min ${ }^{74}$. El hecho de matar a uno de ellos, propietario de tierras en Sevilla desde antiguo, era ya en sí mismo un desafío al poder califal. Además de las menciones expresas a los árabes hilālíes en las cartas, la exigencia de salir de al-Andalus, que nos cuenta también al-Marrākušì y que consiguieron al menos varios grupos al cabo de los años, nos permite afirmar que eran precisamente estos árabes los principales causantes de alborotos tras la derrota de las Navas, aunque desde luego no los únicos.

Resulta llamativa la semejanza entre las descripciones de los daños causados por los almohades al poco de conquistar Sevilla ${ }^{75}$ con estos sucesos, lo que posiblemente apunte al uso de tópicos en la descripción de los hechos, como señalamos anteriormente.

${ }^{73}$ Muharram de 612 corresponde aproximadamente a mayo de 1215.

${ }^{74}$ Aguilar, "Estudio de la historiografía almohade. Un cronista al inicio de una dinastía", p. 14.

${ }^{75}$ Ibn 'Id̄ārī, al-Bayān al-Mugrib, pp. 39-40. 


\section{Carta número $2^{76}$}

Carta dirigida, según el editor, por Abū l-Qāsim al-Balawī al qā'id Abū l-Qāsim b. Muẓanna, que estaba al mando de una ŷiha, término que viene a designar aproximadamente una comarca. Como podremos comprobar, la administración almohade de Sevilla dirigió peticiones a todos los niveles para intentar contener a las tropas árabes, sin que los militares almohades se decidieran a seguir dichas instrucciones, quizá por ser insuficientes sus fuerzas ante ellos o por necesitar su ayuda en caso de un ataque castellano. Resulta notable que no haya habido nombramiento alguno para restablecer el orden como sucedió en otras ocasiones $^{77}$. Esta ausencia, sin ser determinante pues podría deberse a la pérdida del documento, se une a la falta de iniciativa del califato, evidente por el tiempo tan prolongado en que se mantuvo correspondencia por este mismo asunto.

Y junto a esto, que Dios haga aumentar vuestro poderío, lo más importante que tenemos que poner en vuestro conocimiento y en lo que es más necesario el consejo y el informe y la nueva revisión, por lo que afecta a los súbditos de esta región, el mal de los fulāna -que Dios los enmiende- por su orgullo insoportable y sus muchas atrocidades, pues ellos, Dios prolongue vuestros pasos, ya han atacado estas regiones con sus saqueos y han causado gravísimos daños a sus gentes, que han sufrido con ellos opresión, corrupción y trastornos graves. Han traspasado todos los límites, su corrupción es terrible, más allá de toda descripción [...] dejaron a los súbditos entre terrores espantosos que ahuyentan a los fantasmas y a las mismas pesadillas. El pobre espera que lo despojen de su siembra este verano entre fuegos de incendiarios y asesinatos a lanza y a espada. Su situación es de extrema gravedad y su caso es de un peligro insoportable. No se detienen ante nada y saquean día y noche, sin apartarse de ello. Los súbditos han sufrido ya los peores daños y sollozan ante la sede del imāmato [al-hadra al-imāmiyya] con el lamento de Yūsuf -sobre él sea la paz- ante la tumba de Raquel $^{78}$. Y hacen señas con manos que piden ayuda como el que se ahoga entre las olas del mar y llaman a la gente de la orilla clamando ¡socorro! ¡socorro! Y piden clemencia a su imām y a su señor que Dios proteja su luz- con gritos y lamentos.

Ya antes os llegaron noticias de las acciones de este grupo.

76 'Azzāwī, Rasā'il muwaḥhidiyya, carta n. ${ }^{\circ}$ 91, p. 319.

77 Burési y El Aallaoui, Governing the Empire, pp. 365-366, 367-368, nombramientos 32 y 33 .

${ }_{78}$ Aquí hay una referencia que en un principio nos resultaba opaca por una errata de la edición, que indica rạhil (viajero) en lugar de Rāḥịl, el nombre de la Raquel bíblica, es- 
La mención a Yūsuf, además de mostrar la amplia cultura del secretario de cancillería, puede ser una muestra de ortodoxia por parte de éste, que se diferencia de los jāriŷíes, que no aceptaban que la azora de Yūsuf formara parte del Corán ${ }^{79}$. La importancia dada por los almohades a la difusión del libro sagrado en sus dominios, su relevancia simbólica en la traslación del califa almohade ${ }^{80}$, y la tarea de represión de rebeldes con diferentes posturas doctrinales posiblemente motivaron esta cita. Cuando el profeta Yūsuf, vendido por sus hermanos, pasó junto a la tumba de su madre, Rāhịil (Raquel), se arrojó desde lo alto de su camello y dijo: «iMadre! ¡Dirige tus ojos hacia tu hijo! ¡Me han arrojado a una fosa, lapidado y vendido como esclavo!». Entonces Yūsuf escuchó una voz: «¡Ten confianza en Dios!». Si bien este motivo literario no se encuentra en los antiguos textos hebreos, sí encontró difusión en diferentes obras de finales de la Edad Media. La alusión a este episodio en el contexto de la situación de los sevillanos da idea de la crudeza del sufrimiento que experimentaron a manos de los árabes.

Carta número $3^{81}$

Carta dirigida por Abū l-Qāsim al-Balawī a la cancillería almohade en Rabat, aunque al haberse perdido la primera parte no podemos saber con precisión a qué funcionario iba dirigida. Posiblemente, por analogía con las anteriores, fuera enviada a Ibn Ŷāmie.

[...] Y además de esto [...] -que Dios aumente vuestro poder- llegó de vos la explicación de la situación en sus aspectos principales y fue elevado lo que era preciso para terminar con sus efectos y reparar sus perturbaciones. Y esto es así porque los fulāna, que están en estas regiones, las han saqueado, se han comportado con

posa de Jacob y madre de José y de Benjamín (Génesis, 37-45), en la tradición árabe Ya qūb, Yūsuf e Ibn Yāmīn (Corán 12:4-102); cfr. Heller, "Rāhịil”, en EI; al-Ta labī, Qișa al-anbiyā', pp. 69-74; al-Kisā'î, Qișaș al-anbiyā', pp. 155-160; traducción en Thackston, The Tales of the Prophets of Kisā' $\bar{\imath}$, pp. 165-167, 181; Bacher, Zwei jüdisch-persische Dichter. Schahin und Imrānī.

79 Blachère, Introduction au Coran, p. 173.

${ }^{80}$ Bennison, "The Almohads and the Qur'ān of 'Uthmān: The Legacy of the Umayyads of Cordoba in Twelfth Century Maghrib"; Zadeh, "From Drops of Blood: Charisma and Political Legitimacy in the Translatio of the "Uthmānic Codex of al-Andalus" y el ya mencionado estudio de Burési acerca del Corán de la mezquita de Córdoba.

81 'Azzāwī, Rasā’il muwaḥhidiyya, carta n. ${ }^{\circ}$ 92, pp. 320-321. 
la más insoportable presunción y la más espantosa crueldad en aquella parte. Extienden sus manos para derramar sangre, apoderarse de los bienes, las mujeres, de forzar viviendas y vengarse de los súbditos de diferentes maneras que les causan daños, con asesinatos por las armas y el fuego, atacando a los súbditos con las peores torturas, causándoles graves males. Les piden tributos preocupantes y abusivos, les amenazan con quemar sus sembrados y matarlos si no les pagan. Sus abusos provocan quejas y no se mueve nadie para vigilar ni hay nada digno de alabanza en su comportamiento.

La gente de Fulāna ha jurado con los más firmes juramentos, que si no fuera por el grano, de cuya recolección están pendientes, como están muertos de miedo, habrían huido ya de la aldea con sus mujeres y sus hijos. Y en cuanto a la gente de Mengāna, ya se han dispuesto para huir aunque no encuentran forma de llevarlo a cabo ¡Y cuánto zumo tuvo Mengāna el año pasado! dejaron sin él a sus dueños y en cuanto al del futuro, no cuentan con él, según dicen, sus dueños. Los súbditos tienen mucho miedo por sus sembrados este verano ${ }^{82}$. Ya temen por lo que les ha alcanzado, que está en el límite de lo que pueden soportar, pues los fulāna se lanzan en todas las regiones en las que aparecen con igual violencia, forzando las recolecciones y ¿cómo acudirán los dueños de los sembrados, cuando servían como la presa en manos del león? En cuanto a los frutos, los han distribuido entre ellos y no queda para los dueños parte ni fracción alguna, salvo lo desechado por la mano enemiga, y lo que no está ya en buen estado.

Los súbditos se han quejado con el lamento del que está al borde de perecer y piden ayuda como el que se está ahogando; en su súplica se comprueba su desesperación total; han alcanzado el límite tras sufrir los daños más extremos.

Arden por la ira, clamando y exigiendo y llevan sus quejas ante la capital del imāmato, sede de la justicia y de la bondad -que Dios la apoye- una y otra vez, llorando, oprimidos, insomnes, vencidos y desgraciados. Y la sede del imāmato se ha compadecido y es benigna hacia ellos, les tiene afecto y se lamenta por ellos, busca lo mejor para sus siervos y para el país, lo mejor y más noble.

Y vos, si Dios quiere, podéis terminar con este mal de forma clara, alcanzando de Dios una recompensa abundante, pues Dios premia a todo lo que le agrada. Y sucede por el acuerdo con la sede del imāmato -que Dios la apoye y que prolongue su poder-.

Fue escrito el 20 de muharram del año $612^{83}$.

\section{Carta número $4^{84}$}

\section{Según señala el editor, falta el incipit de la carta. Fue escrita por al- Balawī y parece dirigida a Ibrāhīm b. Yūsuf b. 'Abd al-Mu'min, el go-}

${ }^{82}$ Según indica el editor, las cartas setenta y setenta y uno revelan que se trataba de un año especialmente seco.

${ }^{83}$ Correspondiente al 20 de mayo de 1215.

84 'Azzāwī, Rasā’il muwaḥhidiyya, carta n. ${ }^{\circ}$ 93, pp. 322-323. 


\section{bernador almohade de Sevilla en aquel tiempo. La reiteración de las instrucciones a la máxima autoridad almohade en Sevilla muestra la falta de eficacia de las anteriores gestiones, por lo que los daños sobre la población parecen haberse prolongado de forma notable.}

[...] Y a esto, que Dios os conceda fuerzas, en las noticias que llegan a vos de la situación de los súbditos con los fulāna en este momento hay lo que no se puede dejar pasar. Es necesario comenzar y terminar con los informes, pues se teme que si no es por la vigilancia del imām, no se extingan sus llamas. Esto es debido a que clamaron contra el maltrato al que estaban sometidos los súbditos, y acordaron revelar las amenazas y tomar el control de la situación; se propusieron ir contra lo prohibido y lo corrompido.

Atacaron a sus vecinos y se entregaron al derramamiento de sangre, al rapto de mujeres, al robo de bienes y a corromper las cosas, siendo en ello muy obstinados. Alcanzaron los más altos grados de hostilidad, causaron tal terror entre los habitantes de las aldeas que éstos las vaciaron y huyeron de esta plaga; especialmente en la alquería de Fulāna ${ }^{85}$, que se encuentra junto al río [Guadalquivir] huyeron de allí y la dejaron totalmente vacía y nadie se atreve a entrar allí por miedo a ellos. $\mathrm{Y}$ eso a pesar de que anteriormente no habían huido de allí cuando Ibn al-Rink ${ }^{86}$ combatía a los musulmanes de Triana y merodeaba por allí. Sin embargo la aldea de Sant Buš estaba por entonces llena y el miedo no alcanzaba en sus habitantes el grado al que ha llegado con los fulāna, por las torturas y exigencias de distintos tipos a que se ven sometidos.

La gente de los fulāna se apoderó estos días de atrás de un hombre en la alcaicería ${ }^{87}$ mientras que trabajaba en su oficio y dijeron: «iTraed a este para que lo matemos, que es de la aldea de Zutāna!». Los súbditos lo salvaron de sus manos y se encerraron en la alcaicería. La gente temió por sus tiendas y sus mercancías y no abrieron hasta que se hubieron tranquilizado y aquietado. Y aún esto porque estaban respaldados por la cercanía de la inspección imāmí.

Así obraron también en los barrios de Sevilla [arbā lạ lšbilliyya]; entraron en las casas, mataron a hombres y mujeres y se llevaron sus propiedades. El pasado viernes mataron a un jeque que era predicador en Fulāna, y le arrebataron sus ropas

${ }^{85}$ Afortunadamente un par de líneas más adelante se nos relata la identidad de esta localidad, Sant Buš, la actual Santiponce. Acerca de esta localidad, vid. Valencia, Sevilla musulmana, pp. 214-217. La ubicación actual de Santiponce procede del siglo XVII y su localización medieval posiblemente estuviera junto a un brazo, hoy seco, del Guadalquivir, más al norte y más cercano a Triana, en las cercanías de Camas.

${ }^{86}$ Alfonso III de Portugal.

${ }^{87}$ La alcaicería de Sevilla de época almohade estaba tan cerca del alcázar y de la mezquita aljama que este incidente evidencia la pérdida de control sobre los rebeldes de un modo palmario. Esta alcaicería ha sido localizada en las actuales calles Alemanes, Álvarez Quintero, Rodríguez Zapata, Cabo Noral y Florentín; cfr. Valor Piechotta, "Los mercados urbanos", pp. 111-113 y Valor Piechotta, "El mercado de la Sevilla islámica", pp. 233-248, esp. p. 244. No distaba de los muros de la alcazaba almohade de Sevilla más que unos pocos metros. 
cuando volvía, después de dirigir la oración, hacia la ciudad. Y se han multiplicado los ejemplos de este tipo por su parte, que llenan los corazones de temor y miedo. Y la gente, que por su causa están aterrados, se quejan como el que está al borde de la muerte y piden socorro como el que se está ahogando. Extienden sus manos con sus quejas y piden misericordia a la sede del imāmato para que les corresponda con su clemencia. Temen que la vergüenza caiga sobre ellos por sus mujeres, sus hijos, sus bienes y por ellos mismos, [temen que] deban defenderse a sí mismos con sus fuerzas, pues esto les conduce a lo que les desagrada; el remedio de esto es Dios.

En resumidas cuentas, que Dios prolongue tus fuerzas, el asunto de los fulāna ya ha alcanzado un momento crítico y se teme por ello; es imprescindible el celo del Alto Poder y de la sede del imāmato, Dios la apoye, en su cuidado por sus siervos y por la dirección de su país.

La incorporación de varias localidades cercanas a Sevilla dentro de la propia ciudad, debida a la fuerte expansión de época almohade, motivó no sólo una notable extensión del perímetro amurallado ${ }^{88}$, sino la creación de defensas en avance en el territorio, como las fortalezas de Aznalfarache (Hișn al-Faraŷ) ${ }^{89}$, Alcalá del Río o Sanlúcar la Mayor (Šalūqa) en especial para proteger la zona de Triana, unida ya a Sevilla por un puente desde época de al-Mu ${ }^{e} t^{2} i^{90}{ }^{90}$, renovado por los almohades. Por ello la defensa de esta zona en los alrededores de Sevilla era un objetivo importante para los almohades, al que dedicaron una gran cantidad de recursos, pero el hecho de que no fueran capaces de garantizar la seguridad de los habitantes de esta zona ni de las propias puertas de la alcazaba de Sevilla, muestra la quiebra de la autoridad del gobierno mu'miní tras la derrota de las Navas de Tolosa. El que los propios sevillanos se dispusieran a defenderse a sí mismos evidencia igualmente la situación a la que habían llegado las autoridades almohades en aquel momento. Hasta 1224, cuando los sevillanos se lanzaron contra un ejército leonés acompañados de un pequeño contingente almohade cerca de Tejada, dicha amenaza de defenderse por sí mismos no se materializó. El resultado de este encuentro fue catastrófico para los habitantes de la capital hispalense ${ }^{91}$.

${ }^{88}$ Ramírez del Río y Valor Piechotta, "Las Murallas de Sevilla. Apuntes Historiográficos y Arqueológicos".

89 Valor Piechotta, "Hisn al-Faray", pp. 191-193.

${ }^{90}$ Ibn Simāk, al-Hulal al-mawšiyya, pp. 71-72; Ramírez del Río y Valor Piechotta, "Las Murallas de Sevilla", pp. 173-174.

${ }_{91}$ Bosch Vilá, La Sevilla Islámica, 711-1248, pp. 171-173. 


\section{Carta número $5^{92}$}

Según señala al-'Azzāwī en el homenaje a al-Mannūnī, se trata posiblemente, dadas sus características formales, de una carta compuesta por al-Balawī y enviada a Ibn Ŷāmie.

A la capital principal del califato [hadrat al-jilāfa al-'ulyà], del imāmato feliz y precioso [al-imāma al-sa'ìda al-saniyya], centro de las luces espirituales, admonitor de las bendiciones, que Dios aumente sus fuerzas y haga eternos sus días, que acreciente su nombre y eleve sus glorias $[\ldots]^{93}$.

Del siervo de la generosa sede, esclavo de su gran virtud, [...] Ibrāhīm ${ }^{94}$, un saludo generoso y bendito, a la sede de la santidad y la nobleza, con la clemencia y la bendición de Dios, loado y exaltado sea.

Y tras la alabanza a Dios, como conviene a Su majestad, y la bendición sobre el Profeta Muhammad, el elegido y sobre los suyos, y la invocación del imām impecable, el Mahdī, heredero del carácter profético y su hechura, y de los califas bien guiados, los imāmes ortodoxos que condujeron su poderío hasta la máxima extensión, y la invocación por nuestro señor, el califa e imām $A b \bar{u} Y{ }^{\circ} q u \bar{u} b^{95}$, descendiente de los califas bien guiados, de sus grandes esperanzas, de la continuación de su felicidad y de sus victorias en toda circunstancia ${ }^{96}[\ldots]$

En cuanto a lo que concierne al asunto presentado -que Dios lo favorezca- es necesario conocer las noticias de los infieles -que Dios los elimine-, los gastos de la gente de la frontera y su cuidado en estos momentos. Pues saber de ello es importante en todo momento y recabar las noticias de formas diferentes es necesario para asegurar la veracidad de las nuevas. Se sabe, aunque no haya sido autentificado aún, que ellos están en un conflicto interno, entregados a sus problemas y aunque Dios no los haya destruido aún con estos males, esperemos que los aniquile, pues Él destruye a sus enemigos. Esperemos que destroce las regiones del enemigo y bendiga al imāmato ${ }^{97}$.

En cuanto a lo referido por la noble carta en lo ateniente a los asuntos de los Kūmíes -que Dios los conduzca-, es necesario que se presente el siervo ante sus guías, todos ellos; para que sean advertidos contra la continuación de las agresiones. [En caso contrario] habrán de temer el castigo y recibirán lo que se prescribe en el escrito generoso. Y os allana las dificultades por gracia imāmí, que abarca a todo el país y comprende a todos los siervos y por la inspección atenta que persigue lo re-

92 'Azzāwī, Rasā'il muwahhidiyya, carta n. ${ }^{\circ}$ 94, pp. 324-325.

${ }_{93}$ Posiblemente se trate de la carta más retórica y rimbombante de toda la serie, que abreviamos para no agotar la paciencia del lector.

${ }_{94}$ Se refiere, como señalamos anteriormente, a Ibrāhīm al-Balawī, secretario de cancillería muy relevante en la época.

95 Al-Mustanșir bi-Llāh Yūsuf b. Nāșir.

96 Siguen varios párrafos sin interés para otra cosa que la historia de la adulación.

${ }^{97}$ La mejora de la situación militar permitió prescindir de los grupos árabes conducidos en 1212 a al-Andalus; cfr. González, Reinado y diplomas de Fernando III, pp. 245ss. 
probable y la corrupción allí donde se encuentre-que Dios prolongue Su apoyo a la sede del imāmato-pues él les presentó un requerimiento con las intenciones del imāmato y los altos mandatos, que les ordenó cumplir. Y esto mostró sus esfuerzos por ellos -por los súbditos-, con la bendición de la capital del imāmato, que busca la reforma y alaba su influencia, que aumenta el provecho y disminuye los daños, si Dios quiere, y que Dios premie a la sede del imāmato por su compasión con los súbditos, sus siervos, y que Él aumente su apoyo y sus beneficios y que consiga lo que se proponga ¿Que no cese la atención noble, que evite la injusticia y que haga creer al temeroso, que ofrezca buenas nuevas y atienda la llamada del suplicante! En cuanto a lo que ha decretado la supervisión generosa y su gran virtud, la alta inspección cuyo objetivo es cumplir y completar su bondad, con el envío del siervo de la capital suprema, hijo de su siervo, a los Banū Riyāh y a los Banū Waqara Manāf, a forzarlos a vivir en Jerez y a obligarlos a llevar un comportamiento digno de alabanza. Y ésta es una de las bondades que brillan, que fuerzan al agradecimiento al ser humano, [...] Y no resta sino el invocar a Dios para que lo recompense, pues Él es el Poderoso, Alabado sea, para que se cumpla con el agradecimiento debido pues no es la primera de las bendiciones de la sede del imāmato [al-hadra al-imāmiyya], con la que Dios recompensa su atención, ni es la primera gracia que otorga y regala, pues es su costumbre para conquistar los corazones de los jóvenes y de los mayores de sus súbditos y colmarlos de sus bondades, tanto sobre los cercanos

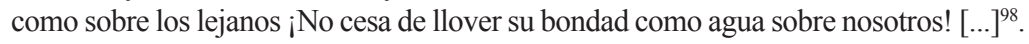

En esta carta aparece reflejada de forma clara la faceta del califa almohade en tanto que dispensador de felicidad sobre sus súbditos, que es uno de los principales lemas de la producción escrita de los almohades, como señaló M. Marín ${ }^{99}$.

La muerte del vencedor de Las Navas de Tolosa, Alfonso VIII de Castilla, condujo a una situación de inestabilidad por la minoría de edad de sucesor, Enrique I, durante la cual las desavenencias entre el conde de Lara y la infanta doña Berenguela causaron graves disturbios ${ }^{100}$. Además, tras la repentina muerte de Enrique I en 1217 fue sucedido por Fernando III, que debió pacificar su reino y sellar la paz con su padre, Alfonso IX de León, objetivo que no alcanzará hasta el pacto de Toro en $1218^{101}$, por lo que el reino de Castilla estará apartado del com-

${ }^{98}$ Sigue un párrafo más de tediosa y repetitiva alabanza que cierra el documento.

${ }_{99}$ Marín, "El califa almohade", pp. 464-471. El epígrafe cubierto en estas páginas se titula "Un vocabulario político: el califa como dispensador de felicidad".

100 González, El reino de Castilla en época de Alfonso VIII, pp. 730-732; González, Alfonso IX, pp. 159-160; Mansilla, La documentación pontificia de Honorio III, pp. 6-8. Este pontífice tuvo gran importancia en la superación de las disputas entre reinos cristianos, como demuestra la cita del acuerdo de Toro «facta secundum mandatum domni pape..».

${ }^{101}$ García Fitz, Relaciones políticas y guerra. La experiencia castellano-leonesa frente al Islam. Siglos XI-XIII, pp. 150-151. 
bate contra los almohades durante este período. No así el de León ni el de Portugal, que aprovecharon la llegada a Lisboa en el verano de 1217 de una escuadra cruzada de holandeses y alemanes que se dirigían a Tierra Santa y que accedieron, a cambio de víveres y de ayuda para rehacer sus barcos, a atacar la fortaleza de Alcacer do Sal (Qașr Abī Dānis). Para defenderla acudieron los gobernadores almohades de Sevilla, Córdoba y Jaén, pero fueron derrotados ante los muros de la fortaleza (25 de septiembre de 1217), tras lo cual cayó dicha fortaleza. Ibn Abī Zar llega a equiparar la gravedad de la derrota en esta batalla con la de Las Navas de Tolosa ${ }^{102}$.

Tras la marcha de los cruzados hacia Palestina y el fracaso del rey de León, Alfonso IX ante Cáceres (noviembre de 1218) ${ }^{103}$ y tras asegurar la tregua con Castilla, la frontera recuperó una cierta estabilidad que permitió una relativa desmovilización de efectivos almohades en al-Andalus.

\section{Carta número $6^{104}$}

Carta presente en el manuscrito de al-Manūnī que, de acuerdo con el último trabajo de 'Azzāwī, había sido escrita por al-Balawī. Una de las alusiones más claras al protagonismo de los árabes en los problemas causados se encuentra en este texto; hay también una serie de alusiones a los negociadores con el reino de Castilla, lo que viene a mostrar la conexión entre la necesidad de contar con los árabes hasta firmar la paz con Castilla.

...Y sus bendiciones -que Dios le premie- hacen brillar sus luces y encienden las sonrisas de los días felices $[\ldots]^{105}$.

Y ha llegado al siervo de su grandeza ${ }^{106}$-que Dios le conceda éxito continuado, le haga conocer un bien permanente en todo tiempo y circunstancia- la noble y excelsa carta, que suscitó una gran alegría y supuso una gran emoción para todos, ya que arregla los asuntos y las circunstancias y asegura la resolución de los problemas de los súbditos, con el traslado de los árabes a lugares despoblados y lejanos ¡Que

${ }^{102}$ Ibn Abī Zar', al-Anīs al-mutrib bi-rawd al-qirțās, p. 242.

${ }_{103}$ Mansilla, La documentación pontificia de Honorio III, pp. 106-107; García Fitz, Relaciones políticas y guerra, pp. 152-153.

104 'Azzāwī, Rasā'il muwahhidiyya, carta n. ${ }^{\circ}$ 95, p. 326.

105 Sigue un párrafo altamente convencional y sin valor informativo ni literario.

106 Parece referirse, como indica el editor de las cartas, al gobernador de Sevilla Ibrāhīm. 
no cesen de dirigirse las miradas iluminadas, impelidas por la virtud, a la alta capital del imāmato! Pues tal es su costumbre, de ocuparse de acciones nobles y de buscar la riqueza del número de acciones piadosas ¡Que Dios la recompense por sus buenos propósitos, sus nobles intenciones y su atención al país! Pues no cesó de defender el país a lanza y a espada y lo cubrió de justicia y de bondad, extendiéndolos en todo momento y lugar ¡Y Dios recompensa a todos los países y a sus siervos! Y cuando llegó la noble carta ¡Que sea honrado quien la trajo! El siervo se aprestó a cumplir con su deber de dar las gracias y se puso a toda prisa a dar forma a lo más importante y a lo más cierto que había pensado. Se cuidó de dar curso a todo lo que se refería en la carta de la sede imāmí - que Dios le conceda éxito-y de llevar a cabo todo ello sin sobrepasarse ni quedarse corto. Y en un instante se puso en contacto con el jeque excelente, el más noble Abū l-'Abbās, hijo del jeque noble y excelso Abū Hafṣ -que Dios prolongue su nobleza- con el dictado de la orden que le había llegado. Y le preguntó cuándo saldría para mantener la importante reunión que le había ordenado ${ }^{107}$.

Se preparó el siervo para la obediencia, a la que estaba dedicado, tras ordenársele que se esforzara todo lo posible. Y contestó el mencionado con un escrito que transmitió a éste su compañero ante la sede imāmí -que Dios la ayude-y en él se apoyó. Y por ello trabaja y se encamina a esforzarse. Y el siervo se empeñó en llevar a cabo lo que le ordenó en todos sus detalles, en toda la medida de sus posibilidades. Y pedimos ayuda a Dios el Altísimo pues Él es la mejor ayuda y la bendición sea sobre el Alto Orden [al-amr al-'azizz], que es ayuda siempre [...] ${ }^{108}$.

\section{Carta número $7^{109}$}

Tras asegurar las paces con Castilla y la tranquilidad de la frontera, las autoridades almohades procedieron a devolver al norte de África a los árabes hilālíes llegados a al-Andalus para las campañas de Las Navas. Su mal comportamiento hace que las autoridades insistan en que sean reprendidos antes de volver al norte de África, lo que muestra el daño causado a la imagen del imperio almohade entre los andalusíes.

[... y junto a esto -que Dios aumente vuestro poderío y nobleza- no dejamos de trasladar a los g $\bar{u} z \bar{a} t$ almohades - que Dios les de fuerza- que quedaban en la Península, para que vuelvan a sus países ¡Que Dios los devuelva con sus familias y con sus hermanos, pues ha llegado el momento que esperaban! iY que Dios escriba en las hojas de las buenas acciones sus intenciones y obras! Cuando os llegue esta carta nuestra - que Dios aumente vuestro éxito y nobleza- haced acudir a los jefes de los güzāt y leedles esta nuestra carta y hacedles saber su contenido, y dadles a conocer que con el honor que les concede Dios son el principio

${ }^{107}$ En una carta previa se había encargado de una embajada a los cristianos.

${ }_{108}$ Falta el final de la carta aunque posiblemente se trate solamente de un par de líneas.

109 'Azzāwī, Rasā’il muwaḥhidiyya, carta n. ${ }^{\circ}$ 96, p. 327. 
de todo bien, tanto del general como del particular. Sus oficiales se distinguieron sin intervención de otros y no les arrebató ninguna otra familia el mérito.

Precaveos de que no pasen otros diferentes de los que habiten con ellos aquí y distinguidlos de los demás de forma que no haya dudas. Luego dirigíos con ellos hacia Tarifa después de haber pedido perdón a las gentes del país, para sellar la buena acción que hicisteis con el $\hat{y} i h \bar{a} d$. Y no os apartéis del cruce hasta que se haya concluido su paso, cumpliendo con las condiciones impuestas.

Ellos son lo blanco de las páginas, están libres de pecado, y reprimen a sus manos; de intenciones limpias, recompensados por Dios. Conoced quiénes están allí de los combatientes árabes pues el trabajo es claro: que sean recompensados en sus lugares de origen, por lo que ordenamos no mezclarlos. Por el trabajo a ellos encomendado, que fue elogiado, y por la invocación aceptada, si Dios quiere. $\mathrm{Y}$ esto es vuestro socorro y vuestra función.

El saludo noble sea con vosotros, con la clemencia y las bendiciones de Dios.

Escrito el 13 de ša bān del año $616^{110}$.

Resulta evidente que los árabes instalados en los primeros tiempos del dominio almohade siguieron establecidos allí, mientras los reclutados para las campañas de al-Nāșir sí fueron retirados de la península Ibérica.

La situación militar en las fronteras entre los almohades y los cristianos ha sido descrita por García Fitz ${ }^{111}$ y evidencia la necesidad de mantener a las tropas árabes en el territorio al menos hasta la firma de la tregua de 1219, aunque a partir de esa fecha las incursiones de diferentes grupos cristianos y los desórdenes internos dificultaron el traslado de estas tropas al norte de África.

Los problemas de convivencia entre andalusíes y almohades han sido destacados ya en diferentes ocasiones ${ }^{112}$, y como podemos observar, la presencia de los árabes hilālíes vino a acrecentar estas dificultades.

\section{Conclusiones}

Las razones de la caída del imperio almohade han sido debatidas en la amplia bibliografía que aborda la historia de este movimiento.

110 Correspondiente a 24 de octubre de 1219.

111 Relaciones políticas y guerra. La experiencia castellano-leonesa frente al Islam. Siglos XI-XIII, pp. 144-149.

112 Viguera Molins, "Un texto recogido por al-Wanšarīsī sobre diferencias en aspectos de culto entre la autoridad almohade y un imām mālikí de Sevilla entre 1171 y 1213", pp. 265-267; Viguera Molins, "Las reacciones de los andalusíes ante los almohades", pp. 705735, esp. pp. 723-724 y 729 . 
Son muy variadas y no es posible simplificar y reducirlas a una o dos; sin embargo el avance de los grupos árabes a los que los almohades habían derrotado en Túnez y deportado al actual Marruecos, está claramente entre las más destacadas.

La actuación de los árabes hilālíes en la península Ibérica apenas ha recibido atención, si exceptuamos su participación en el ejército almohade. Sin embargo sus consecuencias parecen haber sido graves; a lo largo de varias décadas ocuparon regiones de importancia vital para el califato almohade, como la Estepa de Écija, y los gobernantes norteafricanos hubieron de fortificar numerosas plazas, como Écija, Marchena, Osuna... para recuperar el control sobre el mismo. También contribuyeron a socavar la autoridad almohade sobre otros grupos del ejército, como los bereberes kūmíes, que también provocaban disturbios aprovechando la debilidad del gobierno almohade.

Además, la incapacidad de las autoridades almohades para frenar las rapiñas de los hilālíes contra la población durante varios años, contribuyó sin duda a destruir la confianza de los andalusíes que, como se llega a afirmar en una carta de la propia cancillería almohade, tenían menos miedo a los cristianos que a los árabes. Por otro lado, la imposibilidad de enviar refuerzos de este tipo desde el norte de África, dado que causaban más problemas de los que resolvían, sin duda condicionó los esfuerzos del califato almohade para permanecer en al-Andalus en los años siguientes.

Las cartas de la cancillería almohade, que han contribuido al estudio de los almohades desde hace casi un siglo, siguen aportándonos novedades, y son una de las fuentes de las que podemos esperar aún importantes aportaciones.

Resulta necesario llevar a cabo más estudios acerca de este aspecto, pero parece claro que la actuación de los árabes hilālíes en al-Andalus resultó mucho más dañina de lo que pensábamos hasta estos momentos y puede ser un elemento relevante, entre otros, en el derrumbe del poder político musulmán en el Occidente de al-Andalus durante el siglo XIII. 


\section{Bibliografía}

'Abd al-Wāhịid al-Marrākušī, al-Mu'ŷib fì taljịs ajbār al-Magrib, Reinhart Dozy (ed.), The History of the Almohades, Leiden, 1845, reimp. Ámsterdam 1968; E. Fagnan (trad. al francés), Histoire des Almohades, Argel, 1893; A. Huici Miranda (trad. al español), Lo admirable en el resumen de la Historia del Magreb, Tetuán, 1955.

Abū Ishạā Ibrāhīm b. al-Hasan al-Būnsī, Kanz al-Kuttāb wa-muntajab al-ādāb, Hayāt Qāra (ed.), Abu Dabi, Manšurāt al-maŷmū‘ al-țaqāfi, 2004.

Abu-Nasr, Jamil M., A History of the Maghrib, Cambridge, Cambridge University Press, 1971.

Aguilar, Victoria, “Aportación de los árabes nómadas a la organización militar del ejército almohade", Al-Qanțara, 14, 2 (1993), pp. 393-415.

Aguilar, Victoria, "Estudio de la historiografía almohade. Un cronista al inicio de una dinastía", en Concepción Vázquez de Benito y Miguel Ángel Manzano, Actas del XVI Congreso de la UEAI, Madrid, CSIC-AECI, 1995, pp. 11-21.

Aguilar, Victoria, "Instituciones militares: el ejército", en María Jesús Viguera Molins (coord.), Historia de España Menéndez Pidal, VIII-2. El retroceso territorial de al-Andalus, Madrid, Espasa-Calpe, 1997, pp. 187-208.

'Azzāwī, Aḥmad, al-Magrib wa-l-Andalus fi l-qarn al-sābi', Rabat, s.e., 2008.

'Azzāwī, Aḥmad, "Min nawādir al-maktaba al-mannūniyya", Maŷallat da'wat alhaqq, 370 (2003), pp. 37-63.

'Azzāwī, Aḥmad, Qaḍ̄yā tā'rijiyya jilāl al-'așrayn al-muwaḥhid̄̄ wa-l-marīnī, Rabat, Maṭba'a Ribāṭ Nìt, 2010.

'Azzāwī, Ahmmad, Rasā’il dīwāniyya muwahhidiyya, Maṭba 'a Ribāt Nìt, 2006.

‘Azzāwī, Ahmad, Rasā’il muwahhidiyya, Kenitra, Universidad, 1995.

Bacher, Wilhelm, Zwei jüdisch-persische Dichter. Schahin und Imrān̄̄, Budapest, Für das Achuljahr, 1907.

Bencherifa, Muhammad, Ibn Lubbāl al-Šarǐš̄ , Casablanca, Dār al-taqāfa, 1996. Bencherifa, Muḥammad, Ibn al-Mugāwir al-Šățibì, Casablanca, Dār al-taqāfa, 1994.

Bennison, Amira, "The Almohads and the Qur'an of 'Uthman: The Legacy of the Umayyads of Cordoba in Twelfth Century Maghrib”, Al-Masāq, 19, 2 (2007), pp. 131-154.

Blachère, Régis, Introduction au Coran, París, G.-P. Maisonneuve, 1947.

Bosch Vilá, Jacinto, La Sevilla Islámica, 711-1248, Sevilla, Universidad, 1985. Brett, Michael, Ibn Khaldun and the Medieval Maghrib, Aldershot, Ashgate, 1999. Brett, Michael, "The Central Lands of North Africa and Sicily, until the Beginning of the Almohad Period", en Maribel Fierro (ed.), The New Cambridge History of Islam. II: The Western Islamic World. Eleventh to Eighteen Centuries, Cambridge, Cambridge University Press, 2010, pp. 48-65. 
Brunschvig, Robert, La Berbérie orientale sous les Hafșides des origines à la fin du XVème siècle, París, Adrien-Maisonneuve, 1940-1947.

Burési, Pascal, “D’une péninsule à l'autre: Cordoue, 'Uțān (644-656) et les arabes à l'époque almohade (XIIe-XIIIe siècle)", Al-Qantara, 31 (2010), pp. 7-29.

Burési, Pascal, "Les plaintes de l'archevêque: chronique des premiers échanges épistolaires entre Pise et le gouverneur almohade de Tunis (1182)", en Nuria Martínez de Castilla (ed.), Documentos y manuscritos árabes del Occidente musulmán medieval, Madrid, CSIC, 2010, pp. 87-120.

Burési, Pascal, "Traduttore traditore: à propos d'une correspondance entre l'Empire almohade et la cité de Pise (début XIII ${ }^{\mathrm{e}}$ siècle)", Oriente Moderno, 88 (2008), pp. 297-309.

Burési, Pascal y El Aallaoui, Hicham, Governing the Empire, Provincial Administration in the Almohad Caliphate (1224-1269), Leiden, Brill, 2013.

Burési, Pascal y El Aallaoui, Hicham, "La chancellerie almohade", en Patrice Cressier, Maribel Fierro y Luis Molina (eds.), Los Almohades: problemas y perspectivas, Madrid, CSIC, 2005, pp. 477-503.

Carrasco Gómez, Inmaculada y Romero Paredes, Carmen, “Intervención arqueológica de urgencia en plaza de Giles y Rubio n. ${ }^{\circ}$ 9, esquina a c/ Bodegas, a c/ Berberisa y a plaza de Giles y Rubio n. ${ }^{\circ} 19$ de Écija (Sevilla)", en Anuario Arqueológico de Andalucía 1997, Sevilla, Junta de Andalucía, 2001, III, pp. 575-579.

Carrasco Gómez, Inmaculada y Vera Cruz, Elena, "Intervención arqueológica de urgencia en c/ Bodegas 5 esquina a c/ Merinos. Écija (Sevilla)", en Anuario arqueológico de Andalucía 2000, Sevilla, Junta de Andalucía, 2003, II, pp. 1288-1297.

Collado Ruiz, Adelaida, Romero Paredes, Carmen y Carrasco Gómez, Inmaculada, "Intervención arqueológica de urgencia en un solar sito en calle Merinos n. 38 de Écija (Sevilla)", en Anuario Arqueológico de Andalucía 1996, Sevilla, Junta de Andalucía, 2001, III, pp. 657-663.

Cressier, Patrice, Fierro, Maribel y Molina, Luis (eds.), Los Almohades: problemas y perspectivas, Madrid, CSIC, 2005.

Al-Dahabī, Siyār a 'lām al-nubalā', Beirut, Mu'assasat al-risāla, 1986.

Ferrer, Eduardo (coord.), Arqueología en Marchena. El poblamiento antiguo y medieval en el valle medio del río Corbo, Sevilla, Universidad, 2008.

Fierro, Maribel, "Las genealogías de 'Abd al-Mu'min, primer califa almohade", Al-Qantara, 24, 1 (2003), pp. 77-107.

Fierro, Maribel, The Almohad Revolution. Politics and Religion in the Islamic West During the Twelfth-Thirteenth Centuries, Aldershot, Ashgate, 2012.

Fierro, Maribel, "The Almohads (524-668/1130-1269) and the Hafșids (627932/1229-1526)", en Maribel Fierro (ed.), The New Cambridge History of Islam. II: The Western Islamic World. Eleventh to Eighteen Centuries, Cambridge, Cambridge University Press, 2010, pp. 66-105. 
Florindo Sánchez, Rocío, "Intervención arqueológica de urgencia en plaza de Santa Rita n. ${ }^{\circ} 6$ y 7, Osuna (Sevilla)", en Anuario Arqueológico de Andalucía 2001, Sevilla, Junta de Andalucía, 2004, II, pp. 937-943.

Gallego Ortega, Teófilo, "Ibn al-Mugāwir", Enciclopedia de la Cultura Andalusí I, Almería, 2006, vol. 4, pp. 219-224.

García Fitz, Francisco, Las Navas de Tolosa, Barcelona, Ariel, 2005.

García Fitz, Francisco, Relaciones políticas y guerra. La experiencia castellanoleonesa frente al Islam. Siglos XI-XIII, Sevilla, Universidad, 2001.

García Vargas, Enrique y Díaz Martín, Rafael, "Excavación arqueológica de urgencia en la calle Carrera 35 (Marchena, Sevilla)", en Anuario Arqueológico de Andalucía 1997, Sevilla, Junta de Andalucía, 2001, III, pp. 613-619.

García Vargas, Enrique y Díaz Martín, Rafael, “Excavación arqueológica de urgencia en la calle Zurbarán n. ${ }^{\circ} 2$ (Marchena, Sevilla)", en Anuario Arqueológico de Andalucía 1997, Sevilla, Junta de Andalucía, 2001, III, pp. 610-612.

González, Julio, Alfonso IX, Madrid, CSIC, 1944.

González, Julio, El reino de Castilla en época de Alfonso VIII, Madrid, Escuela de Estudios Medievales, 1960.

González, Julio, Reinado y diplomas de Fernando III, Córdoba, Monte de Piedad y Caja de Ahorros, 1980-1986.

Ḥasan Muhammad Nūr al-Dīn, 'Adī b. al-Riqā' al-'Āmil̄̄, Beirut, Dār al-mawāsim, 2001.

Heller, Bernharn, "Rāhịil”, en Encyclopédie de l'Islam, Leiden, Brill, 1995, VIII, 411.

Fagnan, Édmond, Ibn El-Athir. Annales du Maghreb et de l'Espagne, Argel, Adolphe Jourdan, 1901.

Huici Miranda, Ambrosio, Historia política del imperio almohade, Tetuán, 19561957, (reed. facs. con estudio introductorio de E. Molina y C. Navarro, Granada, Universidad, 2000).

Huici Miranda, Ambrosio, Las grandes batallas de la Reconquista durante las invasiones africanas, Tetuán, 1956, (reed. facs. con estudio introductorio de E. Molina y C. Navarro, Granada, Universidad, 2000).

Ibn al-Abbār, al-Mu'ŷam fi aṣhāb al-qā dì al-imām Abì 'Alì al-Ṣadafì, al-Abyarī (ed.), El Cairo, Dār al-kitāb al-mișrī al-lubnānī, 1990.

Ibn al-Abbār, al-Takmila li-Kitāb al-Ṣila, al-Harrās (ed.), Casablanca, Dār alMaeārif, 1990.

Ibn al-Abbār, Tuhfat al-qādim, Iḥān 'Abbās (ed.), Beirut, Dār al-garb al-islāmī, 1986.

Ibn 'Abd al-Malik al-Marrākušī, al-Ḍayl wa-l-takmila, I, Iḥsān `Abbās (ed.), Beirut, s.e., s.d.

Ibn Abī Zar', al-Anīs al-mutrib bi-rawḍ al-qirțās, Rabat, Dār al-manșūr, 1973.

Ibn al-Atīir, al-Kāmil fì l-ta'rìj, Tornberg (ed.), Beirut, s.e., s.d. 
Ibn al-Jațīb, al-Ihạța fì ajbār Garnāta, 'Abd Allāh `Inān (ed.), El Cairo, Maktaba al-Janŷ̀, 1973-1978.

Ibn 'Idāāì, al-Bayān al-Mugrib. Qism al-muwahhhidīn, al-Kattānī et al. (eds.), Casablanca-Beirut, Dār al-țaqāfa-Dār al-garb al-islāmī, 1985.

Ibn Idrīs, Zād al-musāfir, Beirut, s.e., 1970.

Ibn Jaldūn, al-Muqaddima, Beirut, Dār al-rā'id al-'arabī, 1972.

Ibn Jaldūn, al-Muqaddima, México, Fondo de Cultura Económica, 1990.

Ibn Șāḥib al-Ṣalā, al-Mann bi-l-imāma, 'Abd al-Hādī al-Tāzī (ed.), Beirut, Dār al-garb al-islāmī, 1987.

Ibn Sa īd, al-Mugrib fì hulà l-Magrib, El Cairo, Dār al-ma‘ārif, 1953-1955.

Ibn Sa īd al-Magribī, Ijtișār al-Qidh, Ibrāhīm al-Abyārī (ed.), El Cairo, Dār alma‘ārif, 1980.

Ibn Simāk, al-Hulal al-mawšiyya, Suhayl Zakkār y `Abd al-Qādir Zamāma (eds.), Casablanca, s.e., s.d.

Ibn Zubayr, Șilat al-ṣila, III, al-Harrās et al. (eds.), Rabat, Wizārat al-šu'ūn al-islāmiyya, 1993.

Idris, Roger, La Berbérie orientale sous les Zīrides: Xème-XIIème siècles, París, Adrien Maisonneuve, 1957.

Julien, Charles André, Histoire de l'Afrique du Nord, París, Payot, 1931.

Al-Kisā'̄i, Qiṣaș al-anbiyā', Isaac Eisenberg (ed.), Leiden, Brill, 1922.

Lacoste, Yves, El nacimiento del Tercer Mundo: Ibn Jaldún, Ricardo Mazo (trad.), Barcelona, Península, 1985.

Lévi-Provençal, Evariste, “A Abd al-Wāḥid al-Marrākušī”, en P.J. Bearman et al., Encyclopcedia of Islam, 2nd edition, Leiden, Brill, 1960-2005, I, p. 97.

Lévi-Provençal, Evariste, Documents inédits d'histoire almohade: fragments manuscrits du « Legajo » 1919 du fonds arabe de l'Escurial, París, Geuthner, 1928.

Lévi-Provençal, Evariste, "Trente-sept lettres officielles almohades”, Hespéris, 29 (1941), pp. 1-80.

Maíllo, Felipe, De Historiografía árabe, Madrid, Abada, 2008.

Al-Mannūnī, Muhammad, al-Maṣādir al-'arabiyya li-ta'rīj al-Magrib, Rabat, Ŷāmi'at Muhammad VI, 1983.

Mansilla, Demetrio, La documentación pontificia de Honorio III, Roma, Instituto Español de Historia Eclesiástica, 1955.

Al-Maqqarī, Nafḥ al-ṭ̂̀b, Iḥsān 'Abbās (ed.), Beirut, Dār Șādir, 1968.

Marçais, George, La Berbérie musulmane et l'Orient au Moyen Âge, CasablancaAix-en-Provence, Afrique Orient-Edisud, 1991.

Marín, Manuela, "El califa almohade: una presencia activa y benéfica", en Patrice Cressier, Maribel Fierro y Luis Molina (eds), Los Almohades: problemas y perspectivas, Madrid, CSIC, 2005, pp. 451-476.

Martín Muñoz, Araceli, "Intervención arqueológica de urgencia en c/ Mendoza n. ${ }^{\circ} 3$ a c/ Bermuda de Écija (Sevilla)", en Anuario Arqueológico de Andalucía 1999, Sevilla, Junta de Andalucía, 2001, II, pp. 1015-1017. 
Nicol, N.D., A Corpus of Fātimid Coins, Trieste, G. Bernardi, 2006.

Peña, Salvador et al., El mensaje de las monedas almohades, Toledo, Escuela de Traductores, 2002.

Pérez-Blanco, Pedro y Pérez-Blanco, Rafael, "Protección y tratamiento urbanístico de las murallas medievales de Algeciras", Actas del I Congreso Internacional Fortificaciones en al-Andalus, Algeciras, Uned y Excm. Ayuntamiento de Algeciras, 1998, pp. 111-127.

Poncet, Jean, Paysages et problèmes ruraux en Tunisie, París, Presses Universitaires de France, 1963.

Ramírez del Río, José y Valor Piechotta, Magdalena, "Las Murallas de Sevilla. Apuntes Historiográficos y Arqueológicos”, Qurțba, 4 (1999), pp. 167-179.

Rodríguez Mediano, Fernando, "The Post-Almohad Dynasties in al-Andalus and the Maghrib (Seventh-Ninth /Thirteen-Fifteenth Centuries)", en Maribel Fierro (ed.), The New Cambridge History of Islam, Cambridge, University Press, 2010, II, pp. 106-143.

Ruiz Cecilia, José Ildefonso, "Control arqueológico en la plataforma exterior de la Universidad de Osuna (Sevilla), 2002”, en Anuario Arqueológico de Sevilla 2002, Sevilla, Junta de Andalucía, 2005, pp. 551-552.

Sáez, Pedro, Ordóñez, Salvador y García-Dills, Sergio, "La cerca islámica de Écija", Congreso Internacional Fortificaciones en el Bajo Guadalquivir, Alcalá de Guadaira, Ayuntamiento, 2002, pp. 255-263.

Sánchez Gil de Montes, Jacinto y Salas Álvarez, Jesús, “Intervención arqueológica de urgencia en el solar c/ Asistente Arjona 6-8, Osuna (Sevilla). El arrabal oeste de la ciudad almohade de Uxuna", en Anuario Arqueológico de Andalucía 1996, Sevilla, Junta de Andalucía, 2001, pp. 677-687.

Shatzmiller, Maya, The Berbers and the Islamic State: the Marinid Experience in Pre-Protectorate Morocco, Princeton, Markus Wiener Publishers, 2000.

Soravia, Bruna, "Ibn Qutayba en al-Andalus. La préface à l'Adab al-Kātib dans le commentaire d'Ibn al-Sỉd al-Bațalyawsì”, Al-Qanțara, 25, 2 (2004), pp. 539-565.

Soravia, Bruna, "Les manuels arabes à l'usage des fonctionnaires de l'administration (adab al-kātib) à l'âge classique de l'Islam", Arabica, 52 (2005), pp. 417-36.

Soravia, Bruna, “Un traité andalou d'adab al-kātib d'époque almoravide: l'Ihkām șanāat al-Kalām d'Ibn 'Abd al-Gafür de Séville", en Bruna Soravia y A. Sidarus (eds.,) Literatura e cultura no Gharb al-Andalus, Acts of the International Conference, Lisboa April 13-15 2000, Lisboa, IICT-Hugin, 2005, pp. 181-197.

Taḥsīn Muhammad Șalāh, 'Ad̄̄ b. al-Riqā' al-'Āmilì: hayātu-hu wa-ši'ru-hu, Ammán, Wizārat al-taqāfa, 1999.

Al-Ta'labī, Qișaș al-anbiyā', El Cairo, Dār al-Kutub, 1907.

Tawfìq al-Ṭayyibī, "Banū Hilāl wa-dawru-hum fì l-ŷihād fì Ifrīqiyya wa-l-Andalus ilà nihāyat al-qarn al-sādis/al-tānī 'ašar al-mīlādī”, en Dirâsāt wa-buhūt 
fì ta’rīj al-Magrib wa-l-Andalus, Túnez, Dār al-garb al-islāmī, 1997, II, pp. 73-86.

Terés, Elías, Materiales para el estudio de la toponimia hispano-árabe. Nómina fluvial, Madrid, CSIC, 1986.

Thackston, Wheeler M., The Tales of the Prophets of Kisā' $\bar{\imath}$, Boston, Twayne, 1978.

Torremocha, Antonio, Algeciras entre la cristiandad y el Islam, Algeciras, Fundación Municipal de Cultura José Luis Cano, 1995.

Torres Balbás, Leopoldo, Ciudades hispanomusulmanas, Madrid, Instituto Hispano-Arabe de Cultura, 1971.

Valencia, Rafael, Sevilla musulmana hasta la caída del califato: contribución a su estudio, Madrid, Universidad Complutense, 1986.

Valor Piechotta, Magdalena, "El mercado de la Sevilla islámica”, Miscelánea Medieval Murciana, 18 (1993-1994), pp. 233-248.

Valor Piechotta, Magdalena, "Hisn al-Faray", en Magdalena Valor Piechotta (ed.), Sevilla almohade, Sevilla, Universidad-Junta de Andalucía, 1999, pp. 191193.

Valor Piechotta, Magdalena, "Los mercados urbanos", en Magdalena Valor Piechotta (ed.), Sevilla almohade, Sevilla, Universidad-Junta de Andalucía, 1999, pp. 111-113.

Viguera Molins, María Jesús, "Historiografía", en María Jesús Viguera Molins (coord.), El retroceso territorial de al-Andalus, Historia de España de Menéndez Pidal, VIII-2, Madrid, Espasa-Calpe, 1997, pp. 1-37.

Viguera Molins, María Jesús, "La ciudad almohade de Sevilla", en VIII Centenario de la Giralda (1198-1998), Córdoba-Sevilla, Caja Sur-Universidad de Sevilla, 1998, pp. 15-30.

Viguera Molins, María Jesús, "Las reacciones de los andalusíes ante los almohades", en Patrice Cressier, Maribel Fierro y Luis Molina (eds.), Los Almohades: problemas y perspectivas, Madrid, CSIC, 2005, pp. 705-735.

Viguera Molins, María Jesús, "Un texto recogido por al-Wanšarīsī sobre diferencias en aspectos de culto entre la autoridad almohade y un imām mālikí de Sevilla entre 1171 y 1213", Qurțba, 6 (2001), pp. 265-267.

Zadeh, Travis, "From Drops of Blood: Charisma and Political Legitimacy in the Translatio of the "Uthmānic Codex of al-Andalus", Journal of Arabic Literature, 39, 3 (2008), pp. 321-46.

Recibido: $22 / 03 / 2013$

Aceptado: 04/04/2014 